Arch. histol. jap. Vol.29, No. 1 (1968)

p. $63-102$

Department of Otorhinolaryngology (Prof. Hideo IsHir)

Gunma University School of Medicine, Maebashi, Japan

\title{
Fine Structure of the Plasma Cell in the Nasal Polyp
}

\author{
Te-i Hung （洪 得 意） \\ Received December 28, 1967
}

A considerable number of light microscopic studies have appeared on the tissue of the nasal polyp (Kinugawa 1928, Yamazaki 1954, Yago 1959, Matsumori et al. 1960, Iahinara et al. 1961, Dolowitz and Dougherty 1961). As to electron microscopic studies on this subject, however, only a brief report by Tokumaru (1963) is known.

As revealed by light microscopy, there occur in the subepithelial connective tissue of the nasal polyp besides fibroblasts, lymphocytes, neutrophils, eosinophils, plasma cells (Kinugawa 1928), histiocytes, basophils (Yamazaki 1954), monocytes (Matsumori et al. 1960), and mast cells (Dolowitz and Dougherty 1961) in variable numbers. Among them the plasma cells are, according to KinUGawa (1928), diffusely scattered throughout the subepithelial connective tissue of the nasal polyp; YAMAZAKI (1954) reported that these cells, outnumbering eosinophils, were gathered around blood vessels, terminal portions of the nasal gland and excretory ducts. Also IaHinara et al. (1961) found them infiltrating the perilobular region of the nasal gland.

Although there are many electron microscopic studies on the plasma cells (Braunsteiner and Pakesch 1955, Dohi et al. 1956, Tanaka et al. 1957, Wellensiek 1957, Thiéry 1960, Bernhard and Granboulan 1960, Bessis 1964, Petris and KARLSBAD 1965), relatively few deal with human plasma cells. The bone marrow was used in the majority of investigations on human plasma cells (BRAUNSTEINER et al. 1953, Stockinger 1962, Stobbe 1962, Brittin et al. 1963, Gardat et al. 1963, BRECHER et al. 1964); plasma cells from other organs and tissues, for example, the erosion of the cervix uteri (Watanabe et at. 1956), tonsil (Stoeckenius 1957 a) and gastric mucosa (WeLsh 1960, 1962) were also electron microscopically observed. Nowadays plasma cells are thought to be related to antibody production, though its cytological mechanism has not sufficiently been elucidated. In view of this it seems important to investigate the fine structure of the plasma cells in detail. Thus a report on the ultrastructures of the plasma cells in the connective tissue of the human nasal polyps was attempted in the present study.

\section{Materials and Methods}

Nasal polyps, surgically obtained from 11 patients, aged 16 to 69 years, were used. Without any premedication including local anesthesia, polyps were cut with Gruenwald's nasal cutting forceps or Kraus' snare, and immediately immersed in a $1 \%$ cold osmium tetroxide, buffered according to Caulfield. They were then cut into small cubes about $1-2 \mathrm{~mm}$, and again fixed in the same fixative for about 
90 minutes at $0^{\circ} \mathrm{C}$. This was followed by dehydration in serial concentrations of ethanol, washing in propylene oxide, and embedding in Epon 812 according to LUFT. Thin sections were cut with glass knives on the Leitz's ultramicrotome, mounted on copper grids, and stained with double staining by uranyl acetate and lead hydroxide or with single staining by the latter. The specimens were examined in a JEM-5G and a JEM-7 electron microscopes. The original micrographs were taken at magnification of between 2,200 and 34,000 folds, and then photographically enlarged to desired sizes.

For light microscopy, the tissues were fixed in a $10 \%$ formaldehyde and Bouin's solution, dehydrated, embedded in paraffin and serially cut into $4 / \mathrm{e}$ thick sections, which were stained with hematoxylin and eosin, Heidenhain's iron hematoxylin and azan. The light micrographs served as references in electron microscopy.

\section{Observations}

Plasma cells are distributed for the most part solitarily and scattered in the subepithelial connective tissue of the nasal polyp, but some of them make small

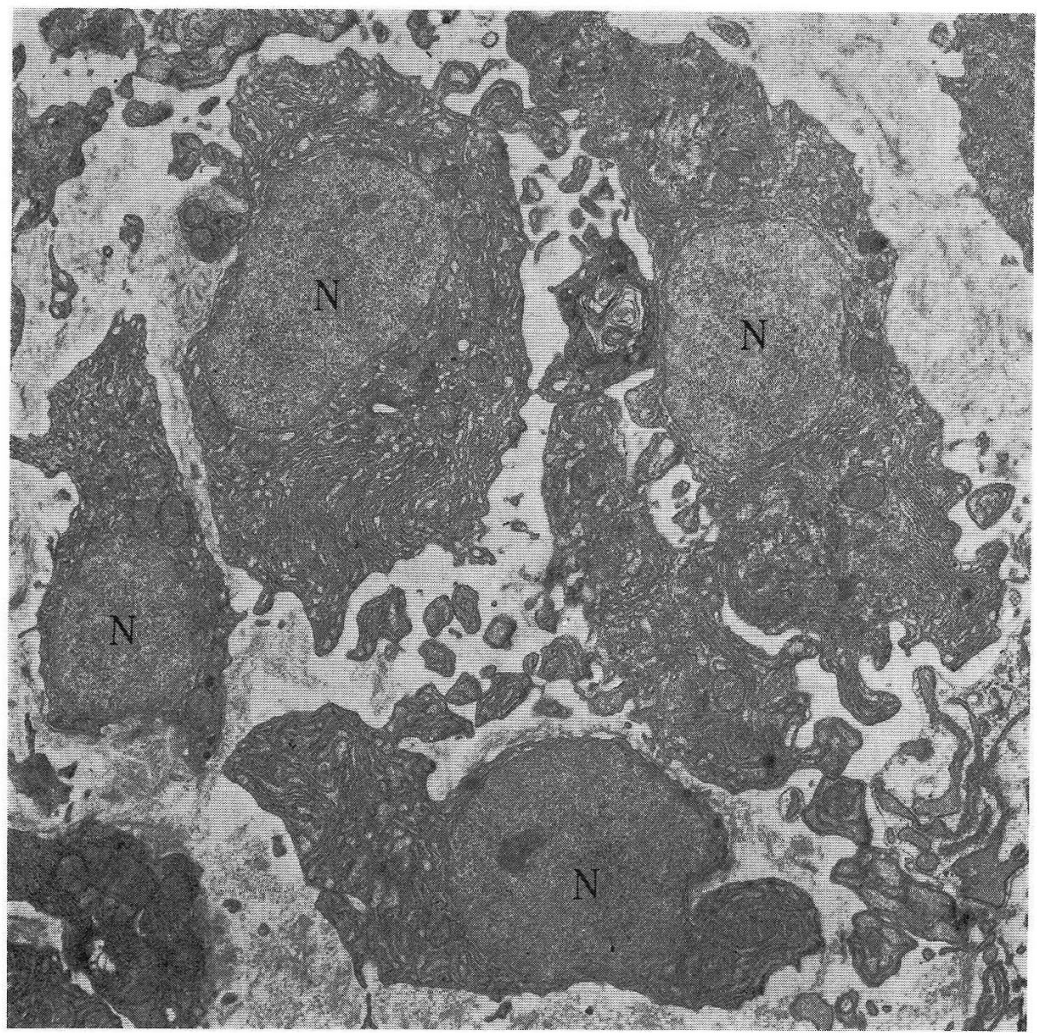

Fig. 1. A survey picture of plasma cells in the connective tissue of a nasal polyp. They are distributed in a small group. The nucleus $(N)$ is eccentrically located and the cytoplasm is filled up with, closely packed ergastoplasmic sacs. From the cell surface numerous cytoplasmic processes of various size and shape are protruded. $\times 5,300$ 
groups (Fig. 1). In general, they are nearly round or elliptical. The surfaces are relatively smooth in some parts, but fairly rugged in others, showing microvilluslike processes and papillary or irregular protrusions larger than microvilli (Fig. 2, 3 ).

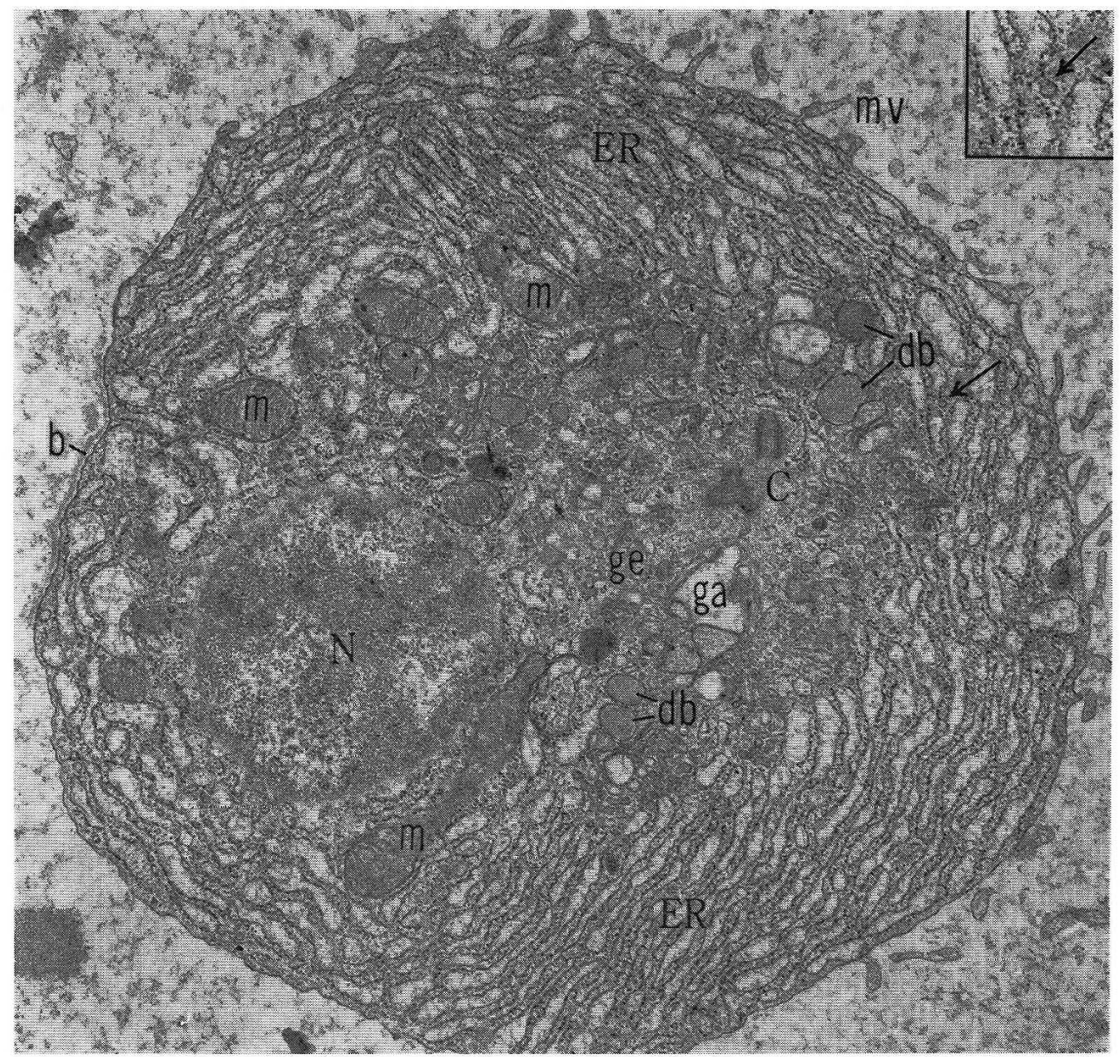

Fig. 2. Round profile of a plasma cell which sends out microvillus-like processes from cell surface. In a large Golgi area adjacent to the eccentrically located nucleus $(N)$ Golgi vacuoles $(g a)$, Golgi vesicles $(g e)$, a diplosome $(C)$ and dense bodies $(d b)$ are seen. $E R$ flattened sacs of the ergastoplasm arranged in lamellar pattern, $b$ basement membrane, $m$ mitochondria. The arrow indicates budding of a smooth surfaced vesicle or a Colgi vesicle from ergastoplasmic sac; its detail at higher magnification is shown in the inset $(\times 28,600) . \times 11,000$

The microvillus-like processes are covered by the plasma membrane; their matrix is homogeneous without any particular structure, and slightly low in density. The cytoplasmic protrusions of various forms and sizes are also covered by the plasma membrane, and contain rough surfaced endoplasmic reticulum (Fig. 3). Frequently these cytoplasmic processes appear in ultrathin sections as isolated cytoplasmic pieces scattered around the cell body. The plasma membrane of the adjoining plasma cells come sometimes in close contact with one another, as seen in Figure 3 ; between the juxtaposed plasma membranes of both cells a narrow cleft about $30 \mathrm{~m} \mu$ in width is recognized. In the peripheral part of the cytoplasm pictures suggesting pinocytosis are rarely visible (Fig. 4). Basement membrane-like structures are frequently seen 


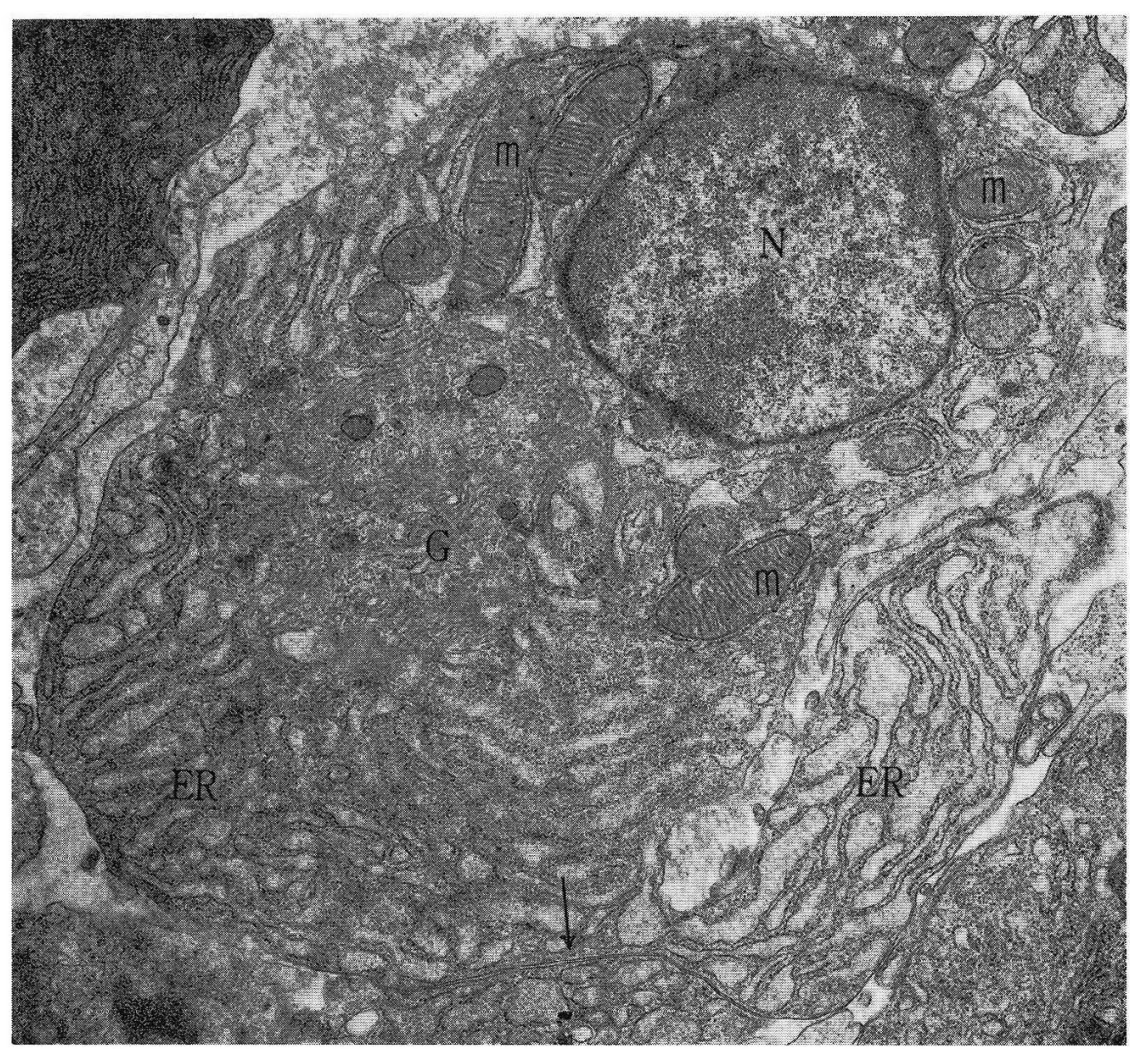

Fig. 3. Plasma cell protruding a voluminous process containing ergastoplasmic sacs $(E R)$. At the bottom it is in a close contact with the neighboring plasma cell (arrow). $G$ Golgi area, $m$ mitochondria, $N$ nucleus. $\times 11,000$

along the surface of the cells, but they are in general not continuous for long distances and never circumscribe the entire cell (Fig. 2).

Nucleus: The nucleus, usually one and rarely two, is in general eccentrically located. It is round or elliptic in form, but frequently has a slight indentation in the nuclear envelope. The double membrane structure of the nuclear envelope is clear. The perinuclear space between the inner and the outer membrane is relatively narrow (about $170-350 \AA$ wide), though in some parts it is greatly distended, with the outer membrane being extruded into cytoplasm. The content of the perinuclear space is usually low in density, but occasionally a dense homogeneous substance of unknown nature is observed filling up the distended part (Fig. 7). Ribosomes are studded irregularly on the external surface of the outer nuclear membrane. Not so numerous nuclear pores, $600-900 \AA$ in diameter, are identified from place to place in the nuclear envelope (Fig. 5). Dense threadlike and granular chromatin materials are irregularly distributed throughout the nucleoplasm, exhibiting string-or net-like structures, and make closely packed, dense irrcgular blocks distributed along the nuclear membrane. This may correspond to the well known specific distribution pattern of the chromatin of the plasma cell: "Radkern" in light microscopy. The 


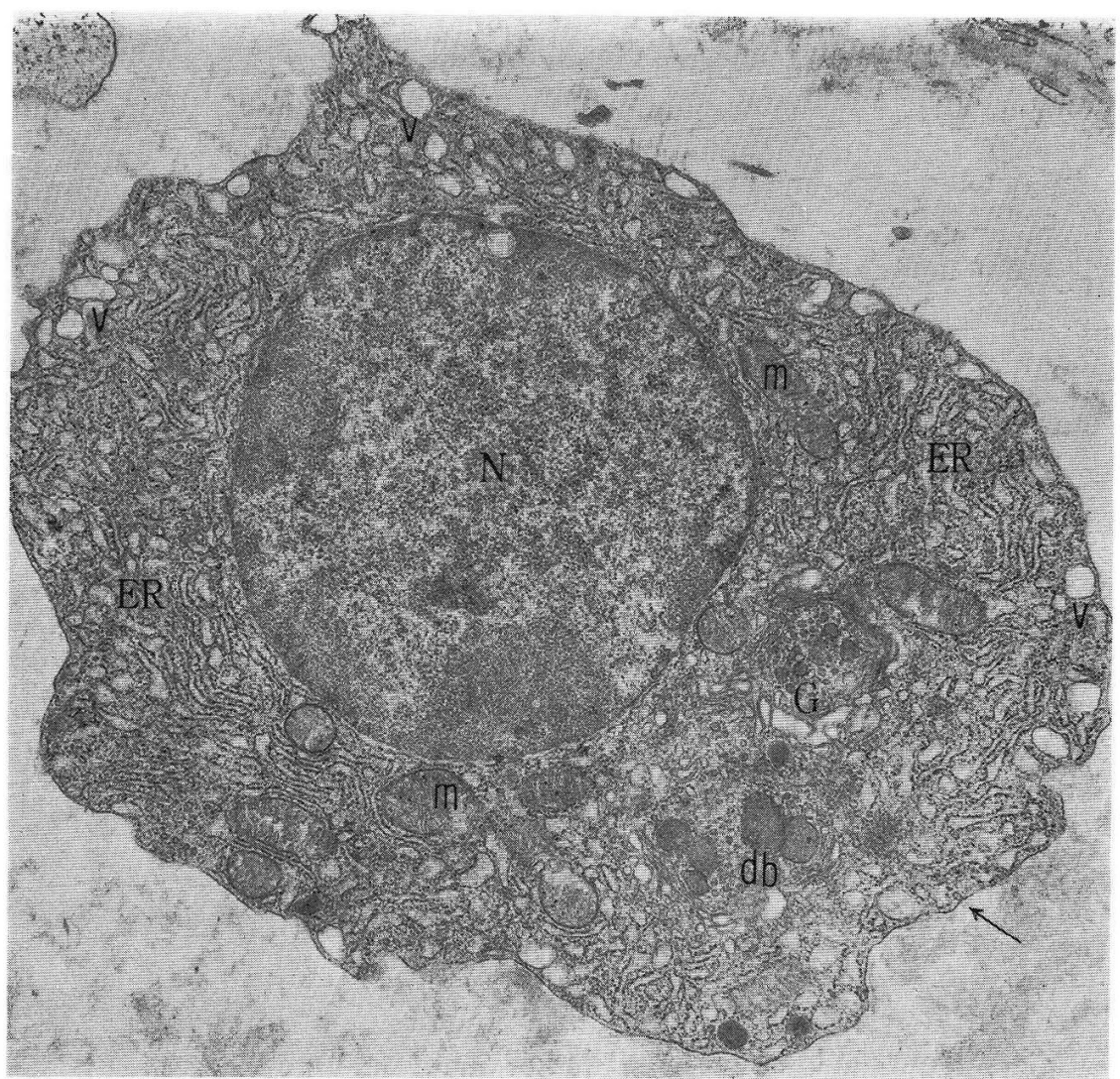

Fig. 4. A plasma cell which possesses in the peripheral cytoplasmic zone, numerous vacuoles limited by a smooth membrane $(v)$. $d b$ Dense bodies within the Golgi area $(G), E R$ granular endoplasmic reticulum, $m$ mitochondria, $N$ nucleus. The arrow points to a pinocytotic vesicle. $\times 9,800$

nucleolus is usually one, and generally located in the center of the nucleus, though sometimes eccentrically. It is composed of closely packed, minute granules of high electron density. The nucleolonema is not clear. Sometimes a plasma cell with two nucleoli can be seen.

Infrequently large round nuclear inclusions are found. They are bounded by a rather faint limiting membrane. It is double layered in some parts, and the inner layer seems to be invaginated toward the interior to form vesicles (Fig. 9). The matrix of these nuclear inclusions comprises very finely granular material of moderate density, which may be distributed closely and evenly (Fig. 8a), or loosely and unevenly (Fig. 9), exhibiting in the latter case string- or net-like structures; still in other inclusions, there occur in the homogeneous, finely granular matrix numerous highly dense granules about $570 \AA$ in diameter, arranged in a net-like pattern (Fig. 8b). Some nuclei contain one inclusion (Fig. 8a, b), but others two (Fig. 9). Their locations in the nucleoplasm are variable, and their limiting membranes are occasionally in contact with the nuclear membrane (Fig. 9). 


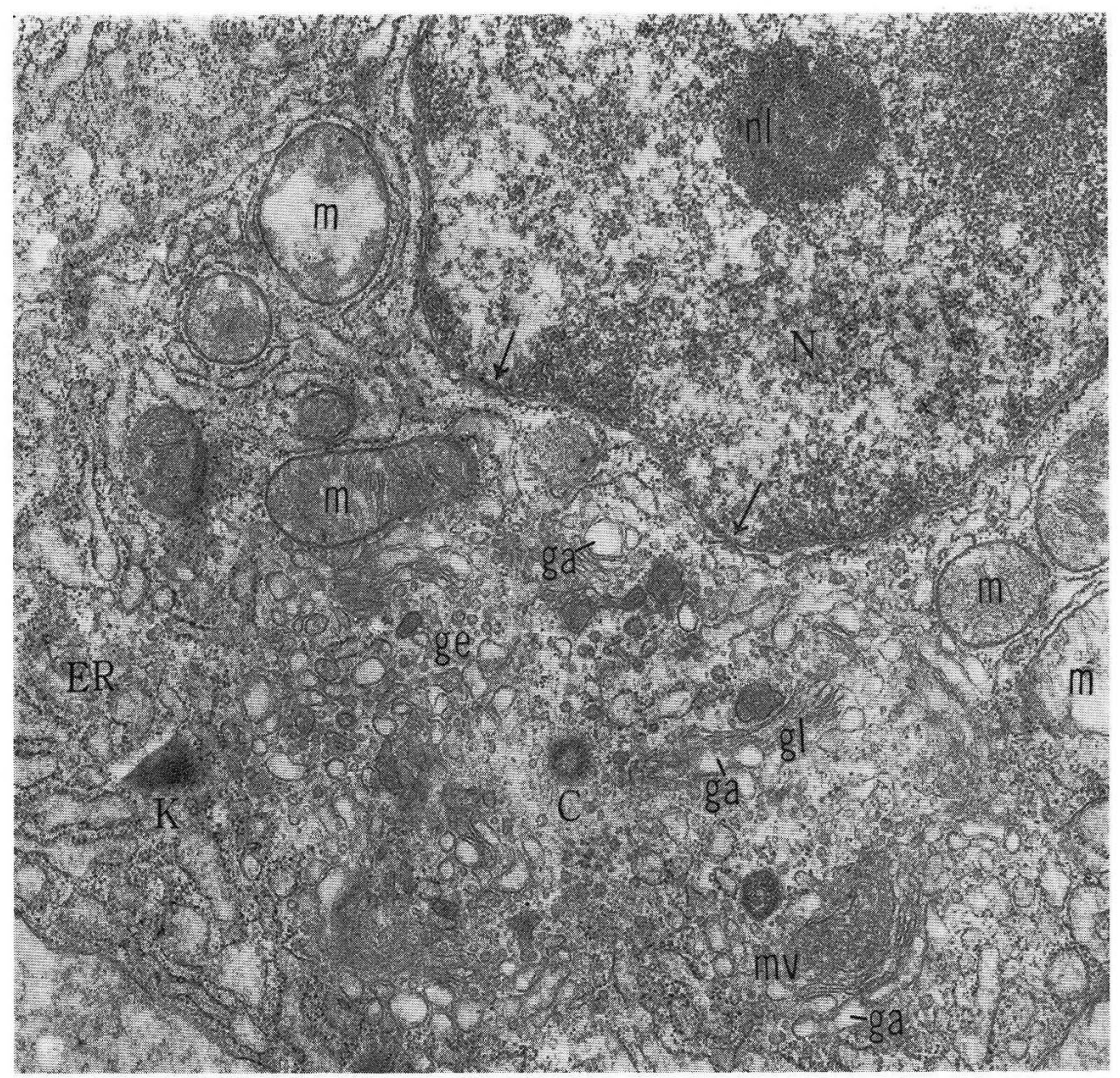

Fig. 5. Nucleolus $(n l)$ containing portion of the nucleus $(N)$ and adjacent Golgi area of a plasma cell. Within the Golgi area a centriole $(C)$, Golgi vacuoles $(g a)$, Golgi lamellae $(g l)$, Golgi vesicles $(g e)$ and a multivesicular body $(m v)$ are seen. Around the area ergastoplasmic sacs $(E R)$, a crystalloid $(K)$ and mitochondria $(m)$ are visible. The arrow indicates nuclear pores. $\times 17,000$

Rough surfaced endoplasmic reticulum: The cytoplasm of the plasma cells in nasal polyps is closely packed with abundant components of the rough surfaced endoplasmic reticulum (ergastoplasm) excepting the Golgi area. The profiles of the components of the rough surfaced endoplasmic reticulum exhibit in general elongated flattened sacs bounded by a limiting membrane which arc arranged in parallel lines and show a lamellar pattern. In some plasma cells the lumina of the flattened sacs are uniformly narrow in their entire length so that their lamellar array is most regular (Fig. 6, 11). In contrast to this, in some other plasma cells the lumina of the flattened sacs have several distended portions showing a variety of widths and the lamellar array has become irregular (Fig. 2, 4). Still in others, the flattened sacs of the ergastoplasm have been transformed, owing to the conspicuous distensions of their lumina, into cisternae, so that the lamellar pattern of the ergastoplasm has almost disappeared (Fig. 3). In one and the same plasma cell, different forms of the ergastoplasmic sacs are observed in different cytoplasmic areas; for example the cytoplasm may be occupied partly by the ergastoplasm of lamellar pattern and partly 


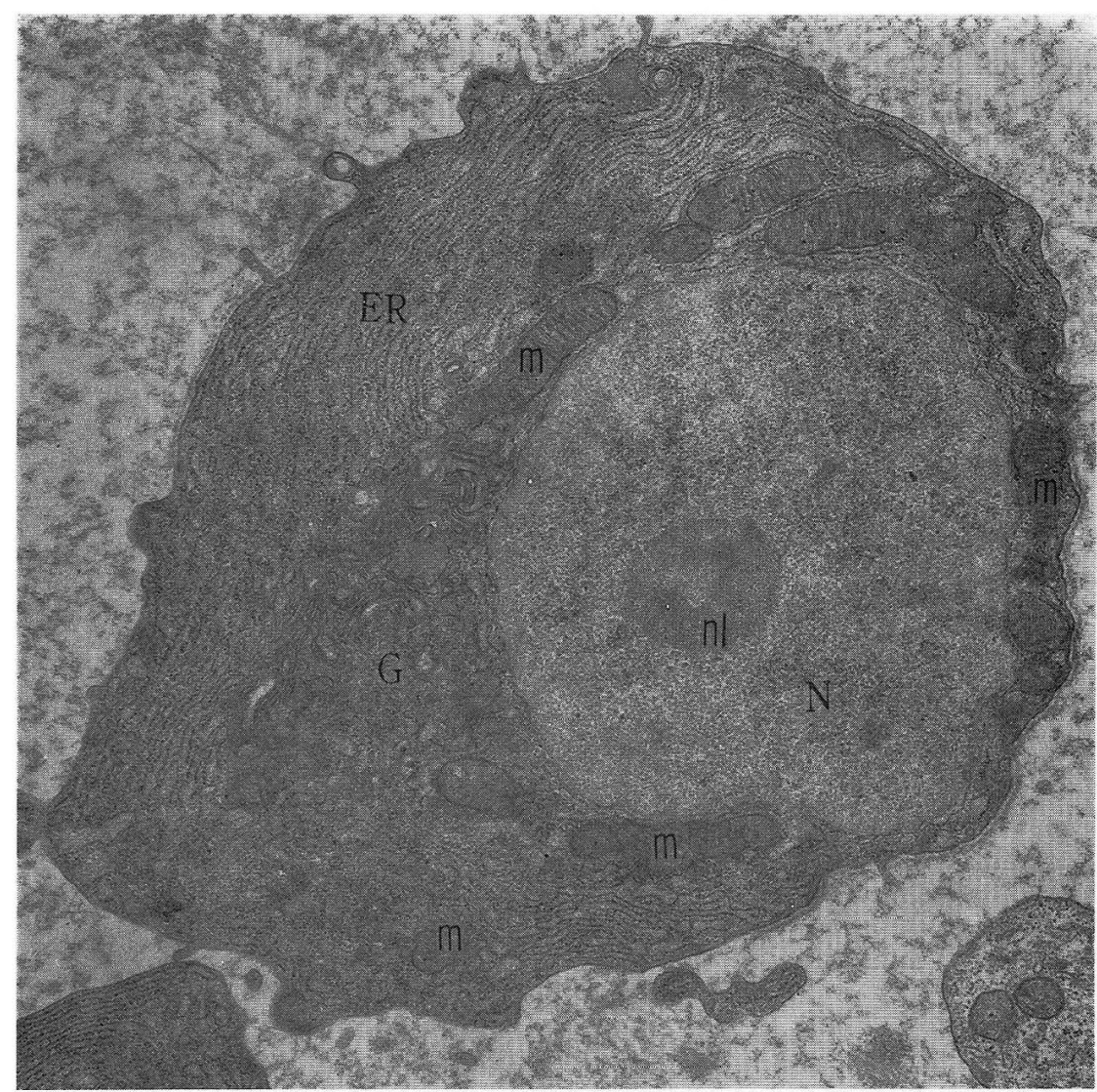

Fig. 6. A plasma cell in which flattened ergastoplasmic sacs $(E R)$ are arranged in a lamellar pattern. The mitochondria $(m)$ are located around the nucleus $(N)$. $G$ Golgi apparatus, $n l$ nucleolus. $\times 10,700$

by conspicuous cisternar distensions (Fig. 10). Ribosomes, about $150-200 \AA$ in diameter, are disposed at varying intervals on the external surface of the limiting membrane of the ergastoplasm, but in some parts they are arrayed at regular spaces. In a plane, probably cutting tangentially to the limiting membrane, it is proved that the majority of ribosomes are studded on it in circular arrangements, intermingling those arranged in rosette-like or spiral disposition (Fig. 11). Besides, a small number of free ribosomes are scattered in the cytoplasm between the ergastoplasm and in the Golgi area. Some of them occur also in small groups of rosette-like disposition (Fig. 2). Near the Golgi area and also in other regions of the cytoplasm, the limiting membrane of the ergastoplasm often extrudes small blebs from which vesicles bounded by a smooth limiting membrane may arise (Fig. 2). The density of their content is higher than that of the ergastoplasm. It may be thought that these vesicles are concerned with the transportation of materials from the ergastoplasm to the Golgi complex. The density of the content of the ergastoplasmic sacs is variable, being in general fine granular or floccular in appearance, showing sometimes a 


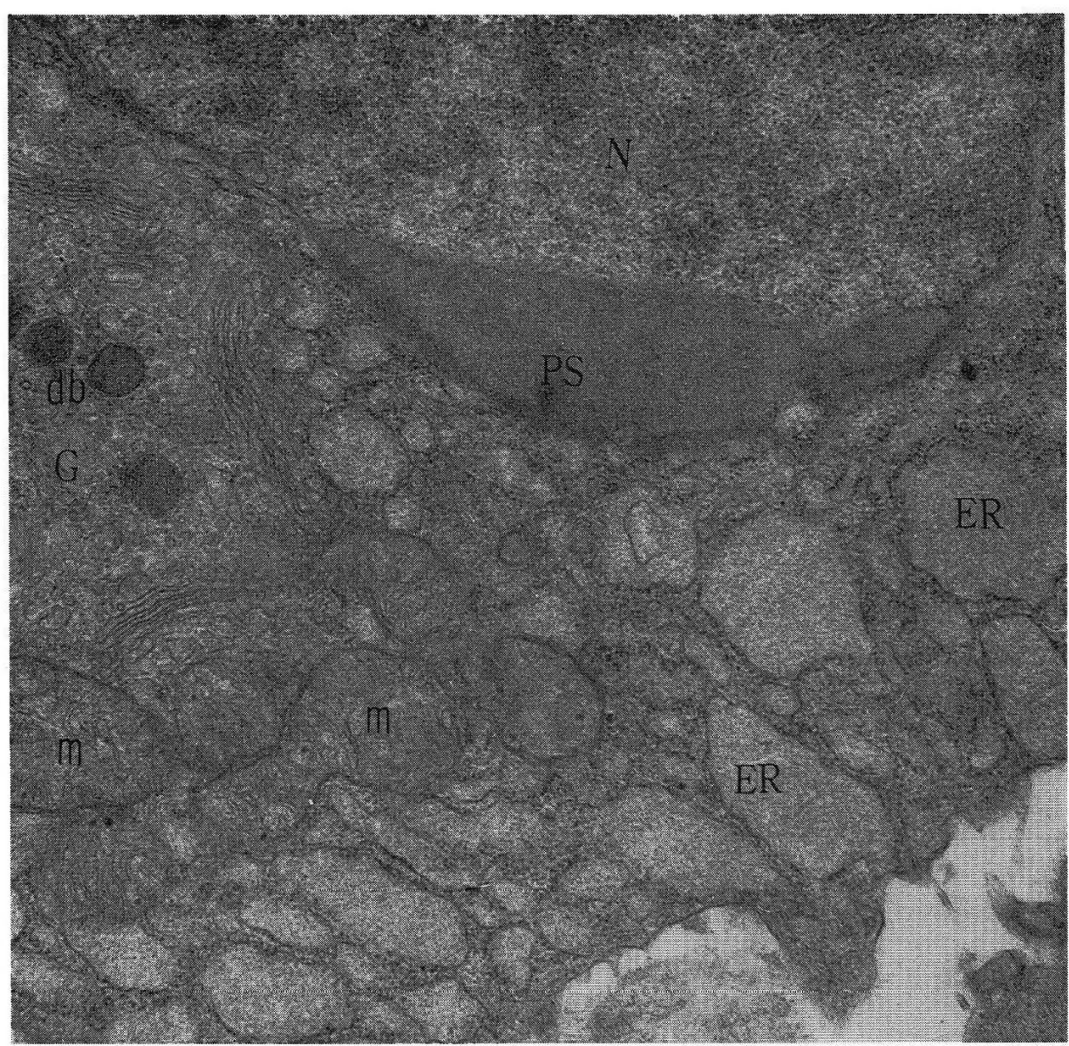

Fig. 7. A portion of a plasma cell including a part of the nucleus $(N)$, the Golgi apparatus $(G)$ as well as a cytoplasmic area containing closely packed, dilated ergastoplasmic sacs filled with homogeneous, finely granular material $(E R)$. The distended portion of the perinuclear space is filled with electron dense, homogeneous substance $(P S) . d b$ dense bodies in the Golgi area, $m$ mitochondria adjacent to the Golgi apparatus. $\times 21,000$

homogeneous, compact texture (Fig. 3, 7), and sometimes a heterogeneous, less compact texture (Fig. 2, 19). The ergastoplasmic sacs contain rarely homogeneous compact masses of high electron density termed "Russell bodies" (Fig. 12, 13, 14) or cross striated crystalline structures (Fig. 15, 17) as will be described later.

Golgi apparatus: The Golgi apparatus is generally well developed in plasma cells. It is located on the central side of the eccentric nucleus, and occupies a large cytoplasmic area near it, forming the so-called Golgi area. The Golgi apparatus consists of Golgi lamellae, Golgi vesicles and Golgi vacuoles. In general, the lamellae and vesicles are predominant and the vacuoles scanty (Fig.4, 18). In some cells, however, the vesicles and vacuoles are prominent in contrast with rather sparse Golgi lamellae (Fig. 2).

Golgi lamellae: The Golgi lamellae consist of several, most frequently 4 or 5, gently curved, elongated flattened sacs bounded by smooth limiting membranes which are closely arrayed in paralleled lines displaying a lamellar pattern. The width of the spaces between the flattened sacs (interlamellar spaces) are almost uniform, 

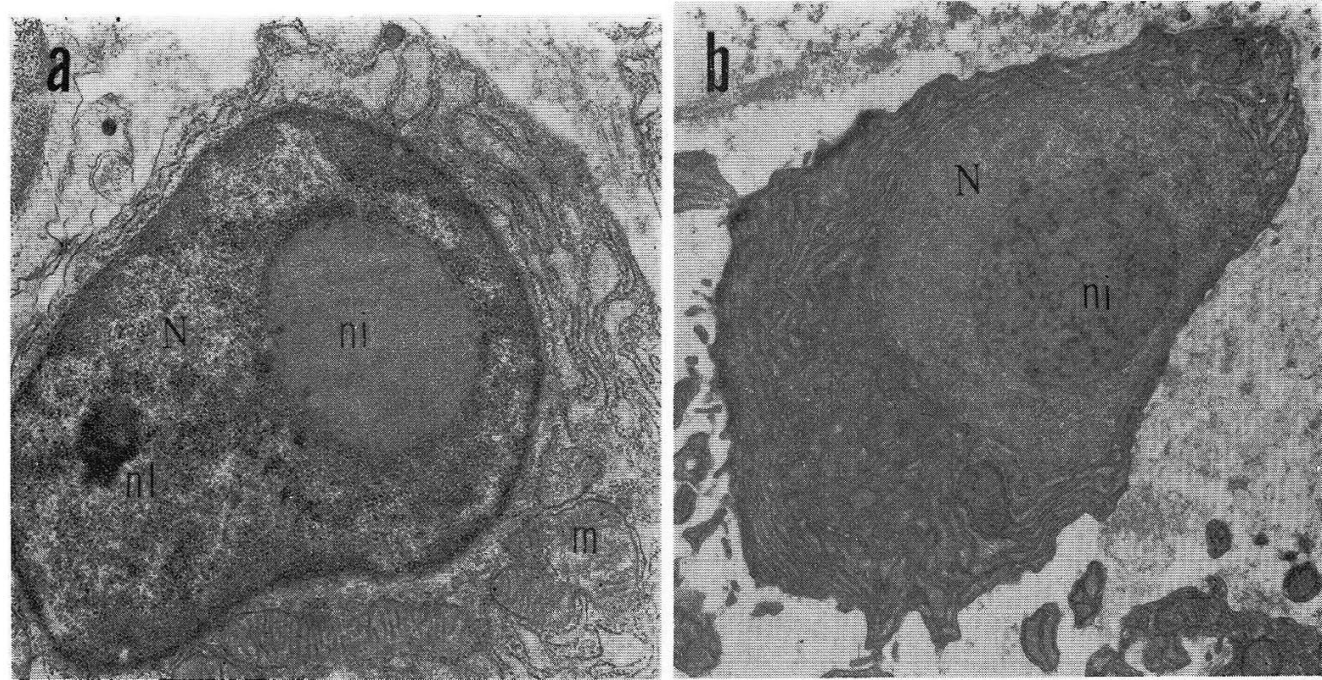

Fig. 8. Nuclear inclusions ( $n i$ ) of plasma cells. a. 'The limiting membrane of the spherical inclusion is indistinct and it contains ultrafine granular homogeneous material. $\times 10,500 . \quad$ b. The limiting membrane is distinct and the interior homogeneous material contains dense granules measuring about $570 \AA$ showing a reticular arrangement. $\times 7,500, m$ Mitochondria, $N$ nucleus, $n l$ nucleolus.

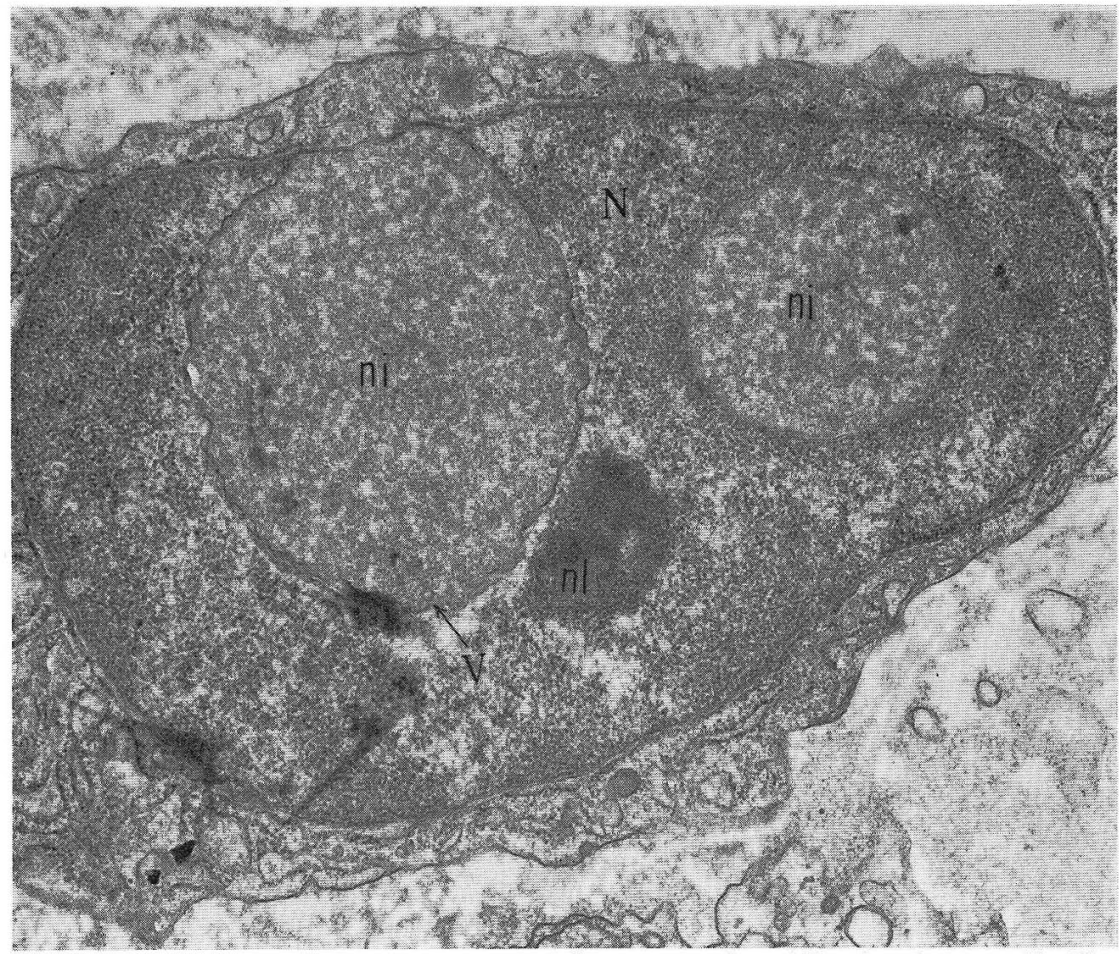

Fig. 9. Two spherical nuclear inclusions $(n i)$ in the nucleus $(N)$ of a plasma cell. The limiting membrane of these nuclear inclusions is partially double. The finely granular contents are not homogeneous. The upper part of the limiting membrane of the left inclusion is in contact with the nuclear envelope. $n l$ nucleolus. The arrow points to a small vesicle derived probably from invagination of the inner membrane of the limiting membrane of this inclusion. $\times 18,500$ 


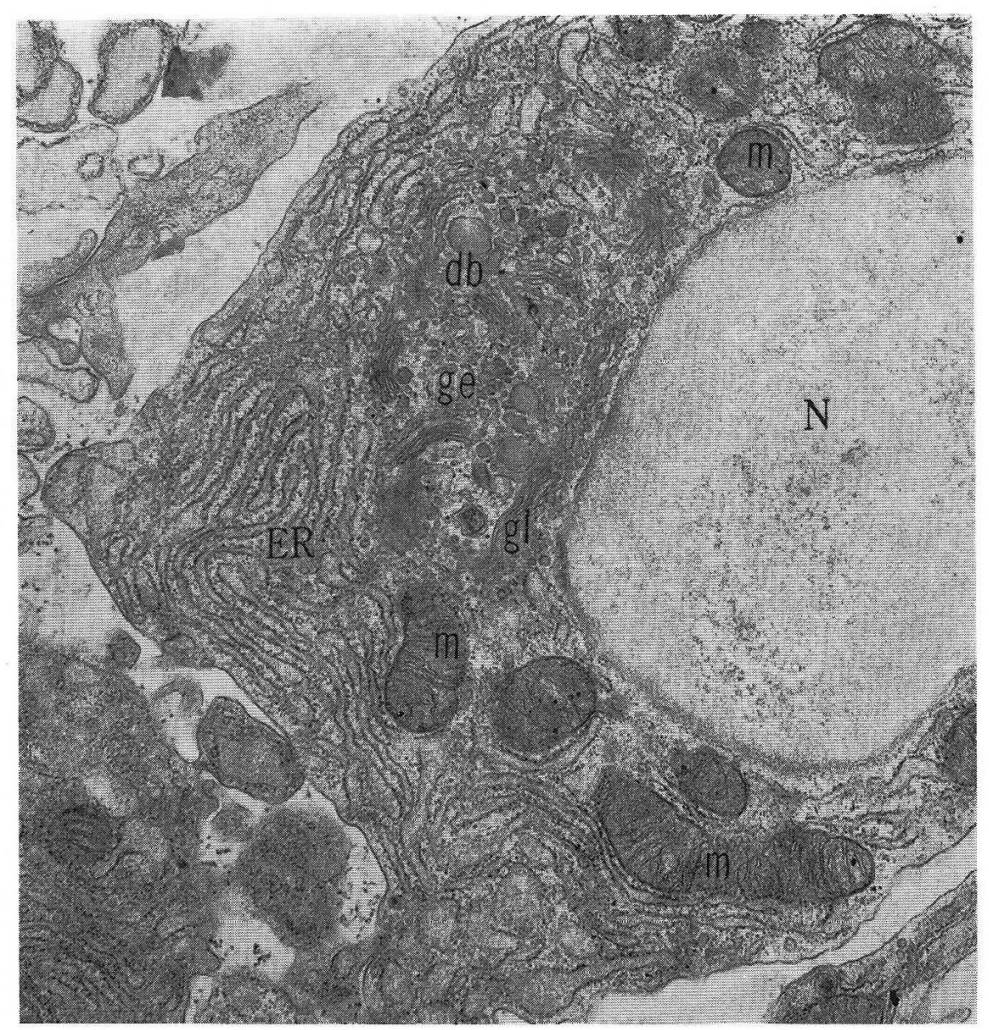

Fig. 10. About one half of a plasma cell containing the Golgi complex adjacent to the nucleus $(N)$. The Golgi apparatus composed mainly of Golgi vesicles $(g e)$ and lamellae $(g l)$, mitochondria $(m)$ and ergastoplasmic sacs in lamellar array $(E R)$ are clearly observed. $d b$ dense bodies in the Golgi area with a rather low clectron density. $\times 14,100$

measuring about $150 \AA$. The lamellae are usually elongated tortuously along the boundary of the Golgi area, sending out some branches toward the interior and make a network as a whole (Fig. 4, 10, 18). The content of the lamellae is in the majority of cases electron dense (Fig. 19), but sometimes they contain less dense material as shown in Figures 4 and 11. The end portions of the flattened sacs of the Golgi lamellae are frequently more or less dilated as described below.

Golgi vacuoles: The sizes (100-400 $\mathrm{m} \mu$ in diameter) and configurations of Golgi vacuoles are variable. Each is bounded with a smooth limiting membrane and contains commonly quite electron-lucent material. The majority of them are located near the Golgi lamellae, indicating a close genetic relation between them. In support of this, such changes have been demonstrated, that end portions of flattened sacs of the Golgi lamellae are in some cases largely dilated exhibiting vacuolar appearances (Fig.4), and in other case they are dilated as a whole and transformed into large vacuoles (Fig. 19). Thus, in the Golgi area in which several Golgi vacuoles are accumulated, the Golgi lamellae occasionally have almost disappeared as shown in Figure 21. On the basis of the above findings, it may be concluded that the Golgi 


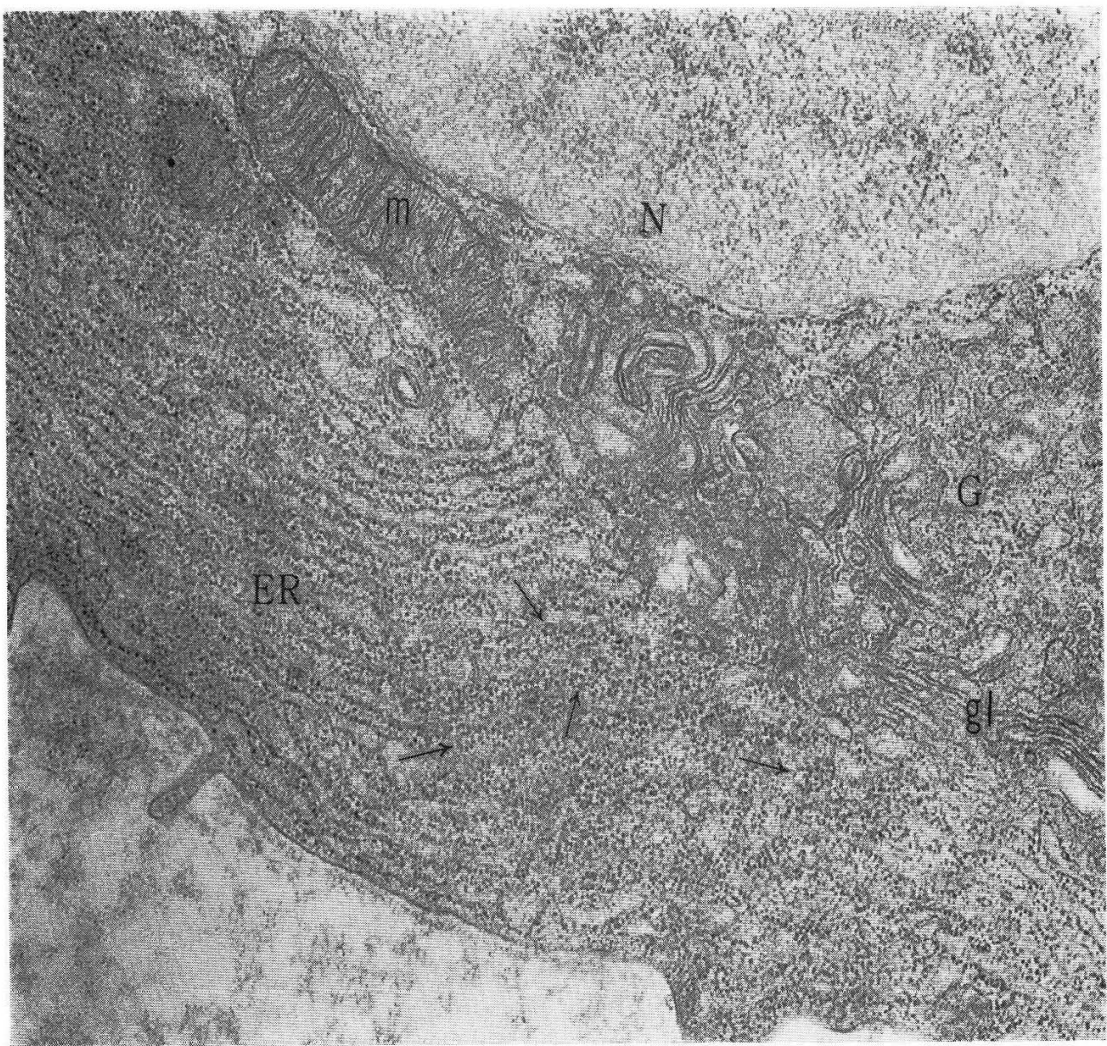

Fig. 11. A higher magnification of a portion of a plasma cell shown in Figure 6, containing a part of the nucleus $(N)$ and the Golgi apparatus $(G)$. In the cytoplasm lamellar array of the elongated, flattened sacs of the ergastoplasm is visible $(E R)$, on which ribosomes are studded partly in a rosette-like circular and, occasional in a spiral arrangement (arrows). $g l$ Golgi lamellae, $m$ mitochondria. $\times 21,800$

vacuoles probably arise from the dilated Golgi lamellae or from the distended ends of them. The electron-lucent content of the vacuoles may be derived from the electron-opaque material contained in the lamellae which dccreases probably in electron density at the time of the dilatation of the lamellae. In the present study the author could scarcely encounter the findings which indicated the later fate of the Golgi vacuoles. However, Figure 4 seems to present some suggestions in this connection: In a plasma cell there occurs a considerable number of smooth membrane bounded vacuoles with electron-lucent content in the peripheral cytoplasmic zone, and some of them closely abut on the plasma membrane, suggesting that their content will finally be released from the cell by means of reversed pinocytosis. These peripheral vacuoles originate probably from the Golgi vacuoles which have emigrated to the peripheral cytoplasm containing the product of the plasma cell. Dilated ergastoplasmic sacs are often seen near the surface of the cell, but there are no findings to suggest that they open directly on the surface plasma membrane and release their contents outside the cell. 


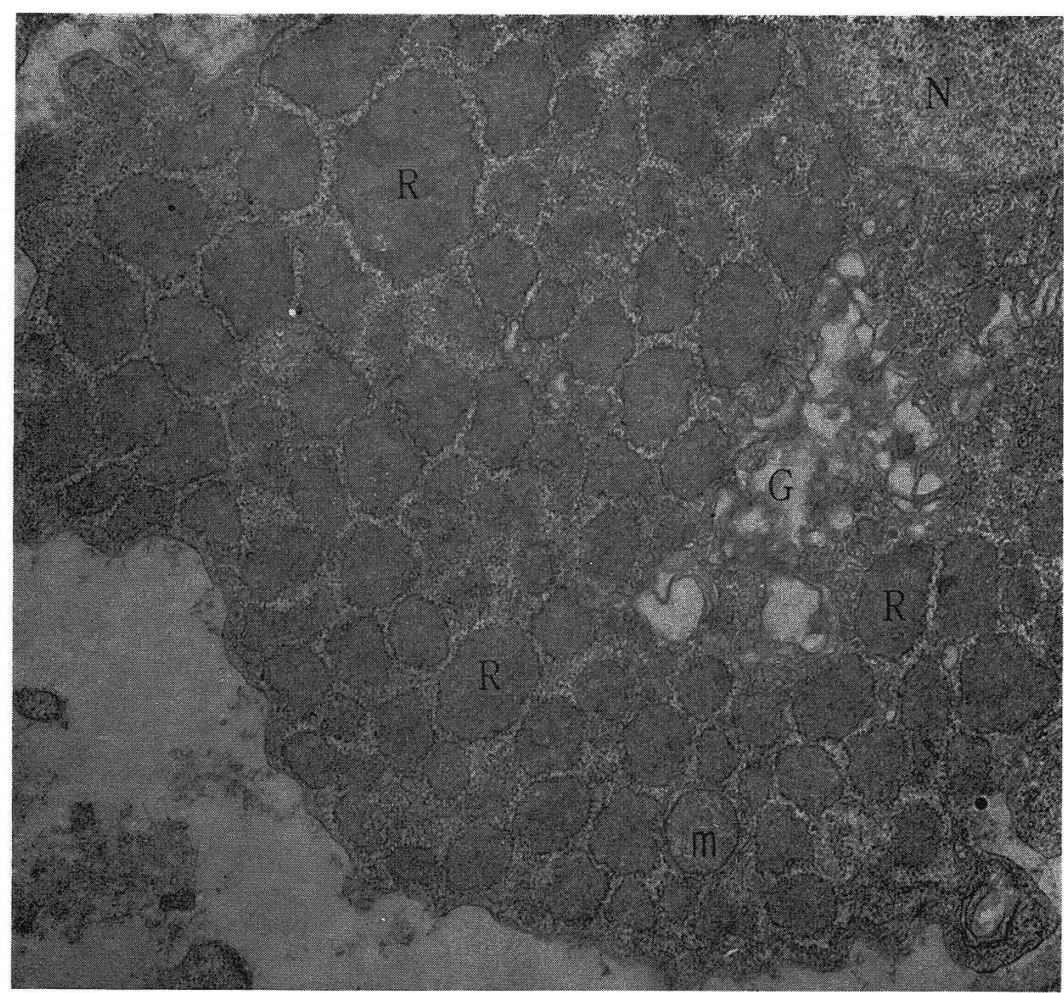

Fig. 12. Numerous closely packed Russell bodies filling up the cytoplasm of a plasma cell. They represent dilated sacs replete with dense homogeneous material $(R)$; between this material and the ergastoplasmic membrane no clear space is seen. Numerous free ribosomes are scattered in the cytoplasmic matrix, but ordinary ergastoplasmic sacs and mitochondria $(m)$ are scarcely seen. G Golgi apparatus showing changes of high degree, $N$ nucleus. $\times 10,200$

Golgi vesicles: Golgi vesicles vary somewhat in size, ranging from $70 \mathrm{~m} \mu$ to $240 \mathrm{~m} \mu$ in diameter. They represent spherules bounded by a smooth limiting membrane. The density of the content is also variable, ranging from a moderate to a high density; some of them are as dense as Golgi lamellae. In the plasma cells found in the nasal polyps, Golgi vesicles are numerous, and distributed along the Golgi lamellae, often making closely packed groups. There seems to be an intimate genetic relation also between Golgi lamellae, since the former are often closely arranged in a line along the latter like a string of beads, suggesting that they will be fused together to form a lamella (Fig. 20 a). As mentioned previously, Golgi vesicles are considered to originate mainly from blebs protruded from the ergastoplasmic sacs near the Golgi area, which are bounded by a smooth limiting membrane devoid of studded ribosomes and may be detached from them to migrate as smooth vesicles to the Golgi area. Within the Golgi area, there occur sometimes a few small ergastoplasmic sacs and free ribosomes, scattered solitarily or in small groups of ring- or rosette-shapes. Occasionally multivesicular bodies are also visible.

Dense bodies (lysosomes): Variably electron dense corpuscles or granules are often 


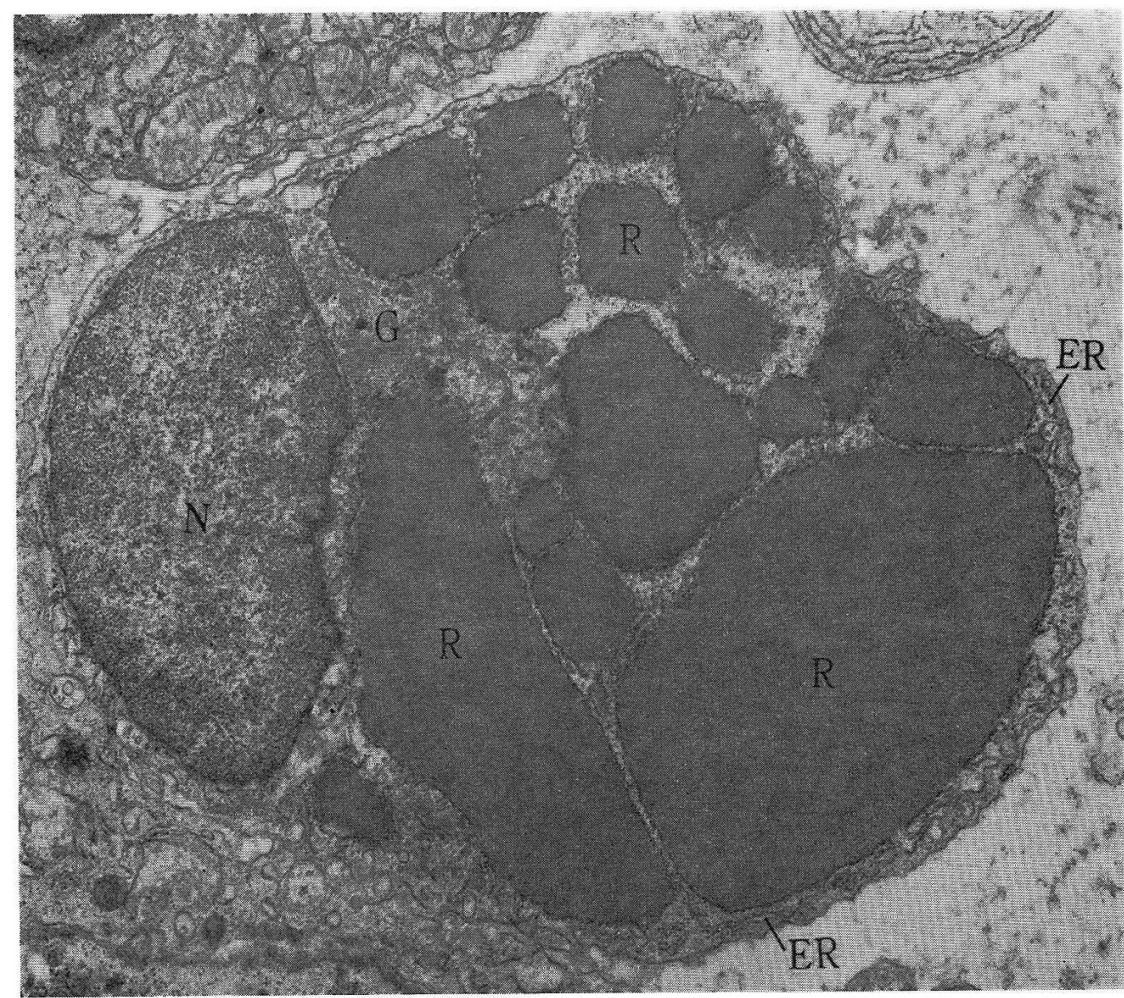

Fig. 13. Large, but less numerous Russell bodies $(R)$ occupying the entire cytoplasm of a plasma cell. They are in ultrastructural characteristics identical with those seen in Figure 12. ER ordinary ergastoplasmic sacs remaining exclusively in the peripheral cytoplasm, $G$ Golgi apparatus, $N$ nucleus pushed toward one cell pole. $\times 8,300$

seen in the cytoplasm of the plasma cell, which may correspond to the so-called "dense bodies" or lysosomes. Many of them are round or oval, but some are irregular in form. Their diameters range approximately from $0.3 \mu$ to $0.85 \mu$. They are always bounded by a smooth limiting membrane. Occasionally there is a clear interstice between the limiting membrane and the matrix of the body. The electron density of the matrix is in general high, though remarkably varying; moderately dense (Fig. 2, 10, 11, 18, 21), fairly dense (Fig. 4, 20 b) and extremely dense ones (Fig. 7, 19, $20 \mathrm{a}$, 28 a) are distinguishcd. The majority of the dense bodies possess a homogeneous and structureless matrix, though there occasionally occur granules much denser than the matrix, electron-lucent vesicles or vacuoles and further, electron-dense membranous structures or myelin figures (Fig. 19, $28 \mathrm{~b}$ ). Dense bodies occur for the most part in the Golgi area or near it, but a few are seen on the opposite side of the nucleus or in the periphery of the cytoplasm. There occur plasma cells devoid of dense bodies, but on the contrary those having a considerable number of dense bodies are not uncommon.

As for the origin of the dense body, it seems to be produced in the Golgi area by fusion of Golgi vesicles. As afore mentioned, Golgi vesicles are fairly high in 


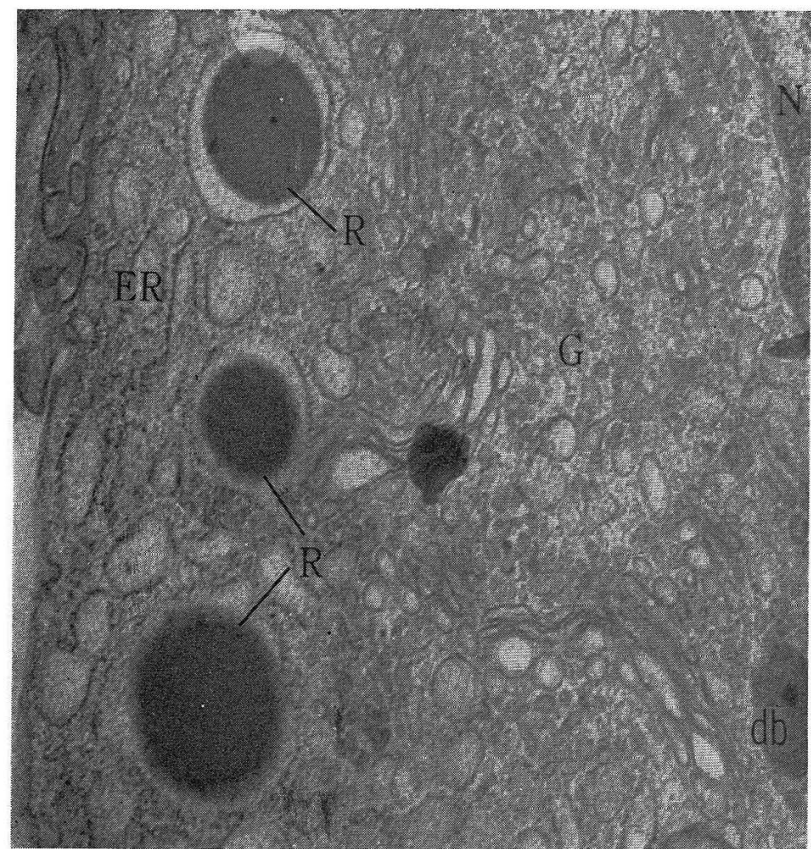

Fig. 14. Russell bodies $(R)$ located near the Golgi apparatus $(G)$. In this case between the central, spherical dense homogeneous materials and the enclosing dilated ergastoplasmic sacs, a clear space is observed just like the intracisternal granules in the dense exocrine cells of the pancreas. $d b$ body, $E R$ ergastoplasm, $N$ nucleus. $\times 26,800$

Fig. 15. A plasma cell replete with transversely and parallel oriented, spindle-or needle-shaped crystalloids $(K)$. They are encompassed with ergastoplasmic sacs applied closely to them. $c l$ Cytolysome containing a degenerated mitochondrion, $E R$ flattened ergastoplasmic sac, $G$ Golgi apparatus containing dense bodies, $m$ mitochondria, $N$ flattened nuc-

$\downarrow \quad$ leus. $\times 8,500$

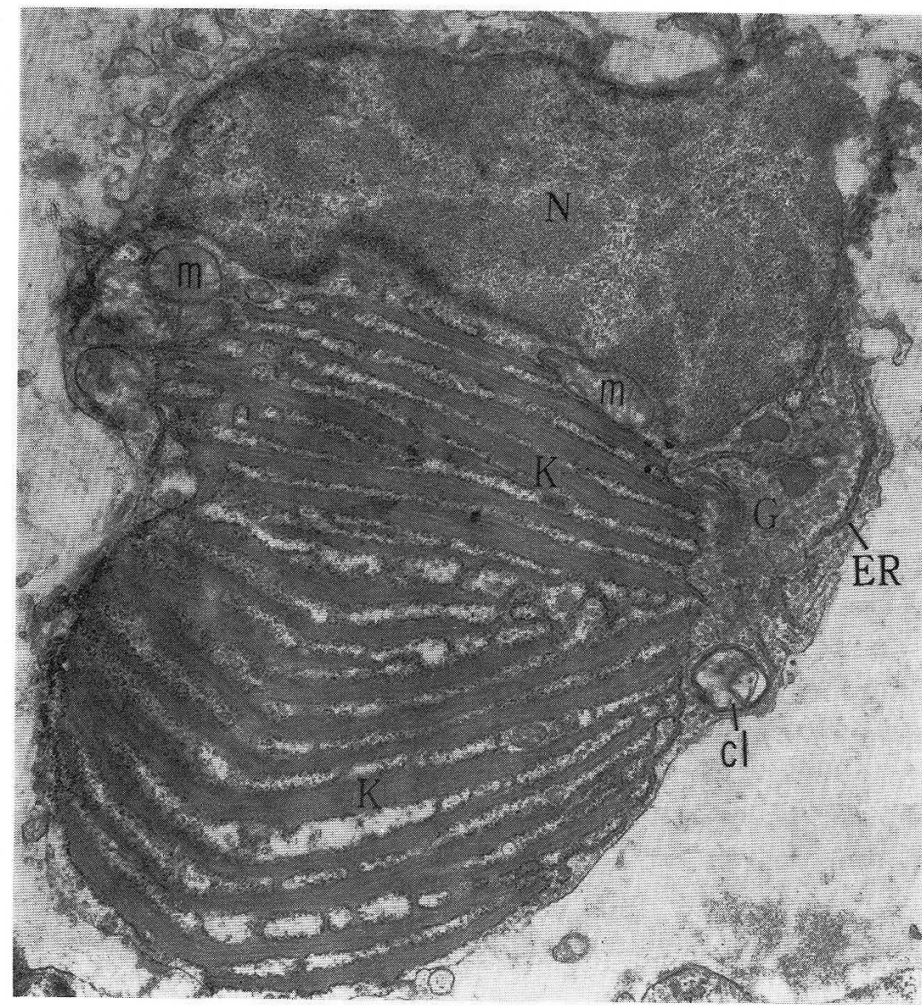



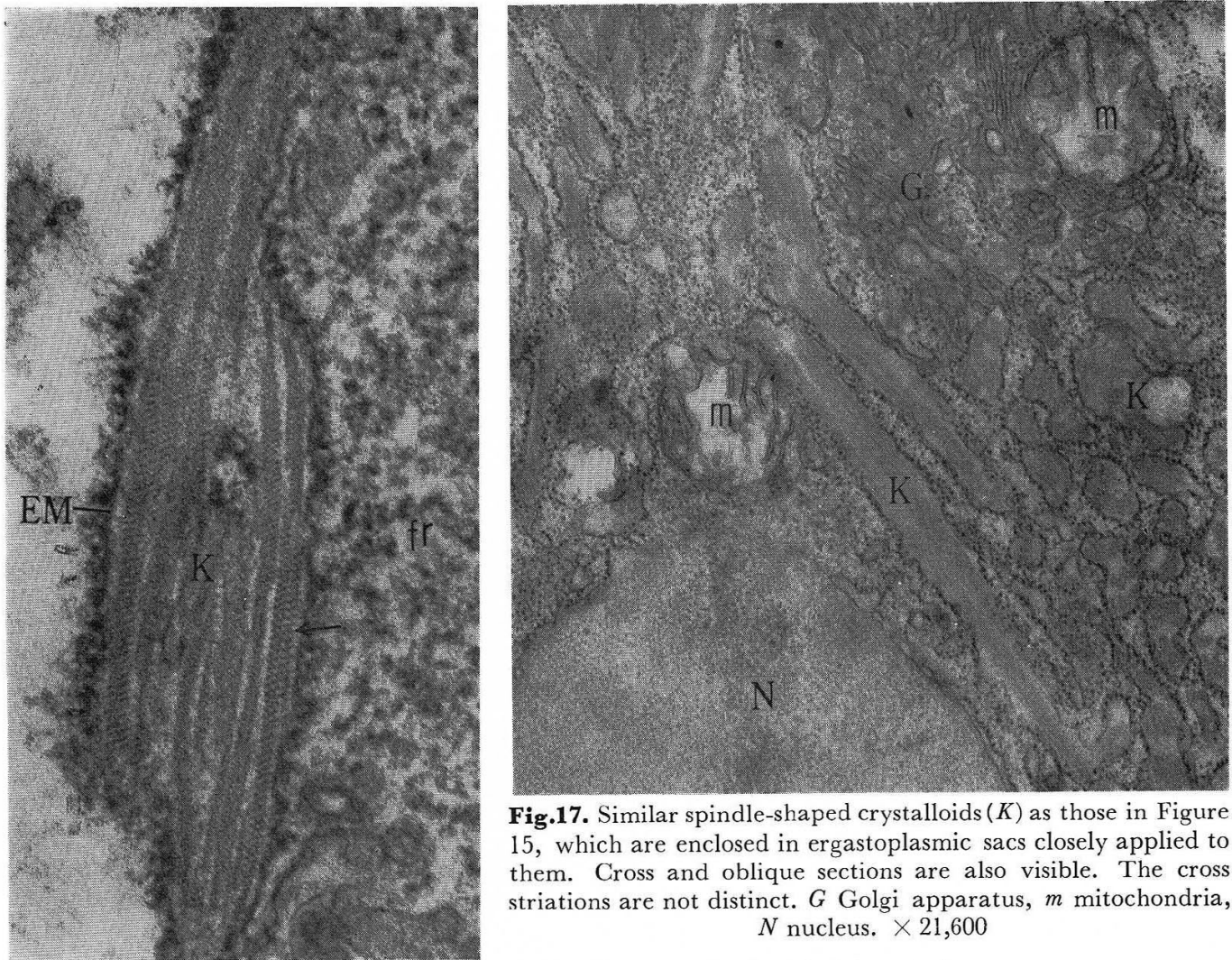

Fig.17. Similar spindle-shaped crystalloids $(K)$ as those in Figure 15, which are enclosed in ergastoplasmic sacs closely applied to them. Cross and oblique sections are also visible. The cross striations are not distinct. $G$ Golgi apparatus, $m$ mitochondria, $N$ nucleus. $\times 21,600$

Fig. 16. A higher magnification of a crystallaid $(K)$ seen in Figure 15. The spindleshaped crystalloid comprises a bundle of several fibrils about 250 thick. They show cross striations (arrow) with a periodicity of about $120 \AA$, which run somewhat obliquely to the long axis of the fibrils. $E M$ ergastoplasmic membrane covering the crystal-

loid, $f r$ free ribosomes. $\times 72,000$

density, and pictures suggesting progressive fusions of such electron-dense vesicles gradually into larger dense bodies have been obtained frequently in this study (Fig. $10,20 \mathrm{~b}$ ). The origin of the interior structures visible in the matrix of the dense body is not clear, but it seems probable that the dense bodies with such interior structures have been derived, at least partially, from the so-called "cytolysomes" which will be described now.

Cytolysomes: In plasma cells of the human nasal polyp, there appear, though rarely, structures which are assumed to be cytolysomes or autophagic vacuoles. They are usually large in size (1.0-1.8 $\mu$ in diameter), round or oval in shape, and bounded by a smooth limiting membrane. They contain a variety of cytoplasmic components such as degenerated mitochondria (Fig. 15, 22 a), ergastoplasmic sacs (Fig. 22 a) and multivesicular bodies (Fig. 22b). These cell organelles are thought to undergo further alterations within the limiting membrane. As afore mentioned, lysosomes containing myelin figures and other internal structures may presumably correspond to aged cytolysomes in which the enclosed organelles have been strongly altered and lost 


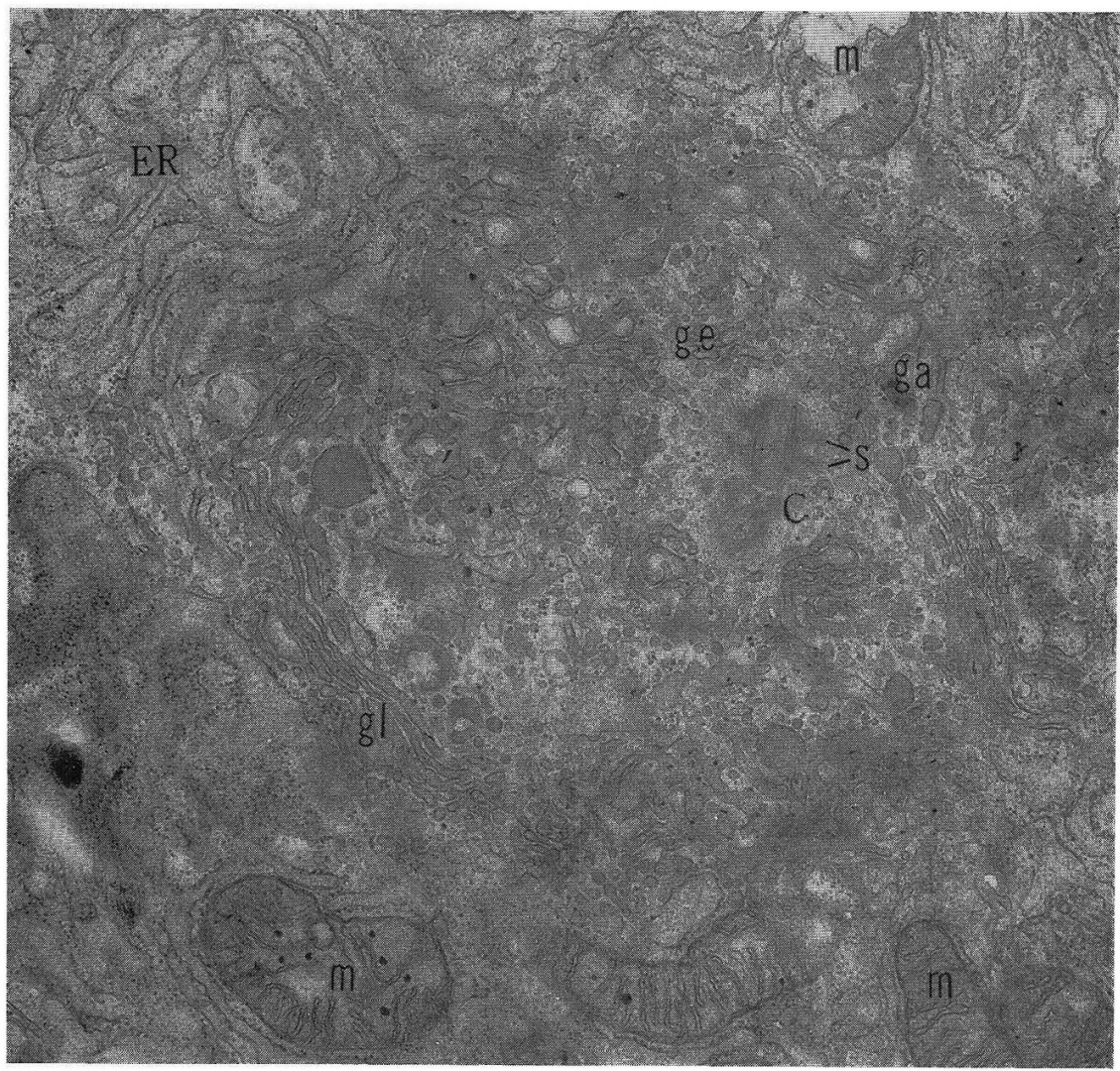

Fig. 18. Golgi apparatus of a plasma cell which are composed of well-developed Golgi lamellae $(g l)$, numerous Golgi vesicles $(g e)$ and sparse Golgi vacuoles $(g a)$. Several dense bodies are also contained. A diplosome $(C)$ is present in the centcr of the Golgi area, of which one centriole possesses two satellites $(S)$ on each side. $E R$ ergastoplasm, $m$ mitochondria containing intramitochondrial granules. $\times 19,100$

their characteristic structures. Some cytolysomes are located in close proximity of the Golgi area, and others in the periphery of the cell.

Mitochondria: In plasma cells of connective tissue of the nasal polyp, mitochondria showing spherical, elliptic, elongated and rod-shaped profiles are observed; occasionally U-shaped, branched, dumbbell-shaped ones are seen. Their distribution in cytoplasm is not uniform being gathered around the nucleus or around the Golgi area. However, occasional ones are scattered among the ergastoplasmic sacs and exceptionally within the Golgi area. Cristae mitochondriales are fairly numerous and closely disposed. In the more or less elongated profiles of the mitochondria, it can be clearly recognized that the parallel arranged cristae mitochondriales are oriented across the long axis of the mitochondrion (Fig. 3, 10, 11). Sometimes branched cristae and their irregular arrangement can be seen. The matrix of mitochondria is usually moderately electron dense similar to that of the cytoplasm, though the density is frequently not uniform as several less dense parts may occur in the matrix. Dense intramitochondrial granules $\left(35-55 \mathrm{~m}_{\ell}\right.$ in diameter) are often 


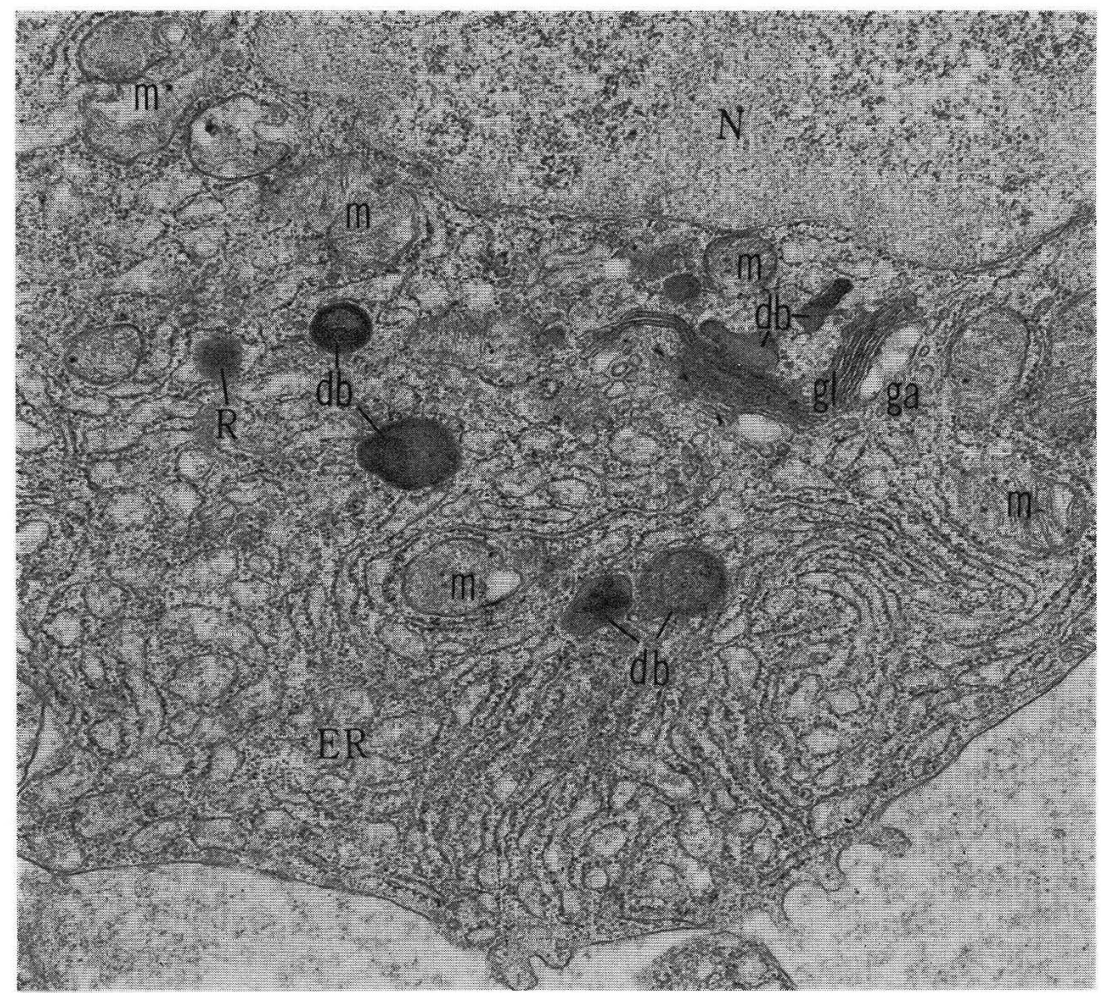

Fig. 19. Dilated ergastoplasmic sacs $(E R)$ and Golgi apparatus adjacent to the nucleus $(N)$. Golgi lamellae $(g l)$ contain dense materials, some of which are dilated to form Golgi vacuoles $(g a)$. Within and outside the Golgi apparatus dense bodies $(d b)$ are seen, and in those outside the Golgi apparatus internal structures of high density are observcd. $m$ Mitochondria, $R$ a Russell body enclosed in a ergastoplasmic sac leaving a clear halo subjacent to the sac. $\times 20,300$

seen in the matrix between the cristac. They vary in number from mitochondrion to mitochondrion, the maximum number observed reaching ten. Rod-shaped granules are rarely found. In highly magnified electron micrographs, it has been revealed that the intramitochondrial granules are made up of densely packed subunits.

Centrioles: In plasma cells, the presence of the diplosome in the Golgi area has already been demonstrated by light microscopy, in the present study, this has been confirmed also by electron microscopy (Fig. 2, 18). However, because of the observations carried out in ultrathin sections, only one centriole of the diplosome has been seen in the majority of plasma cells (Fig. 5, 20). The small cytoplasmic halo around the centrioles lacks Golgi vesicles and ribosomes, forming a rather electron-lucent area with a finely granular appearance. The long axes of both paired centrioles of the diplosome cut each other at varying angles and not always at a right angle. For instance in the diplosomes illustrated in Figures 2 and $23 \mathrm{a}$, the angle is $110^{\circ}$ and $120^{\circ}$, respectively. The centrioles of the plasma cells represent the hollow cylinders as in other cell types. They measure about $470 \mathrm{~m} \mu$ in length, about $210 \mathrm{~m} \mu$ in outside 

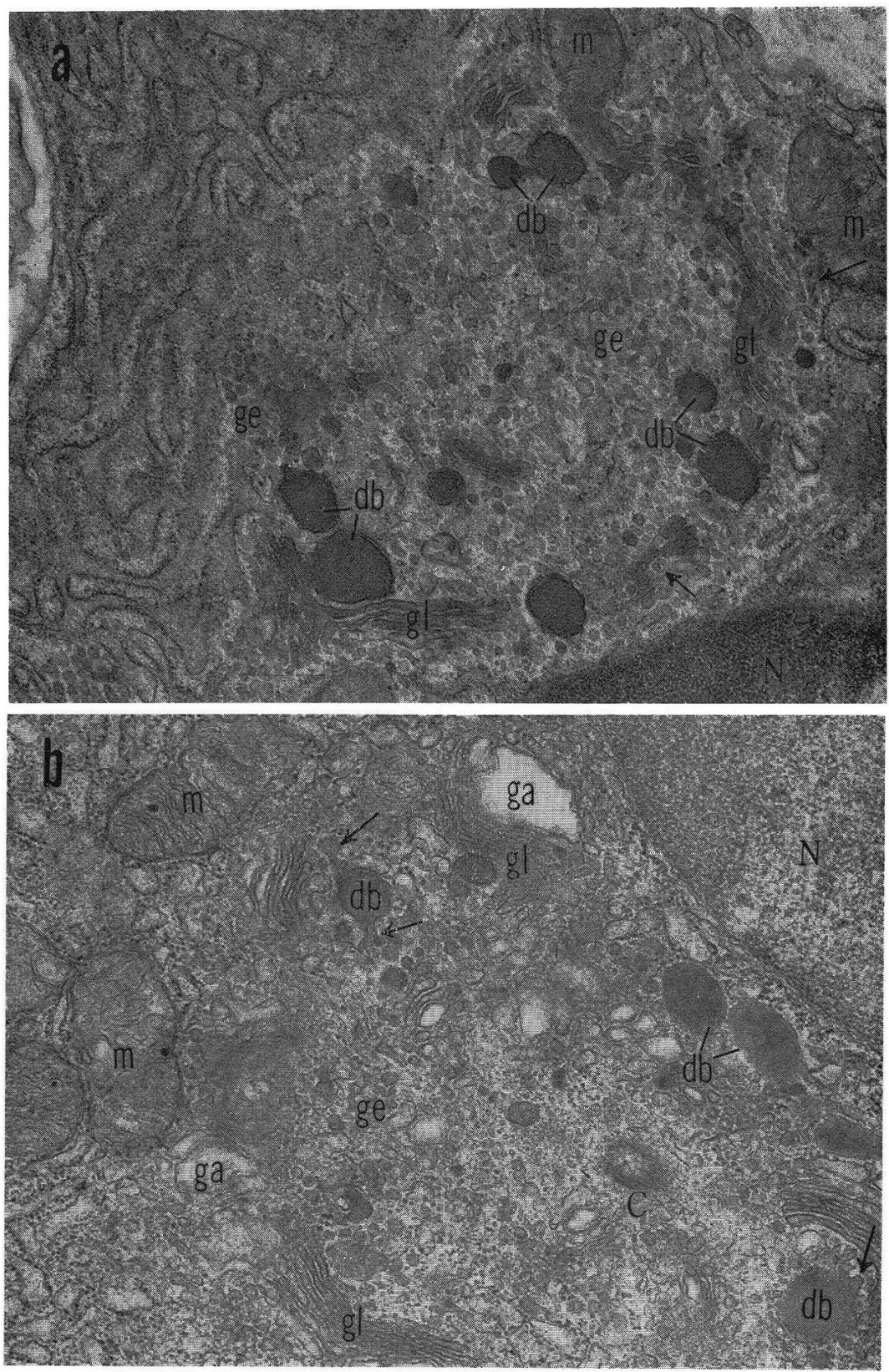

Fig. 20. a. Golgi apparatus of the plasma cell located in the close proximity of the nucleus $(N)$. The majority of the Golgi lamellae $(g l)$ and vesicles $(g e)$ contain dense materials. Golgi vesicles closely aligned in a row along the Golgi lamellae (arrows) suggest the formation of Golgi lamellae by fusion of them. Many dense bodies $(d b)$ of high electron density are seen in the periphery of the Golgi area. $m$ Mitochondria. $\times 20,000$. b. In this Golgi apparatus several fairly opaque dense bodies $(d b)$ are seen and some of them show the pictures which may suggest the formation of the dense bodies by progressive fusion of the Golgi vesicles (arrows). $C$ centriole, ga Golgi vacuoles, ge Golgi vesicles, $g l$ Golgi lamellae, $m$ mitochondria, $N$ nucleus. $\times 26,600$ 


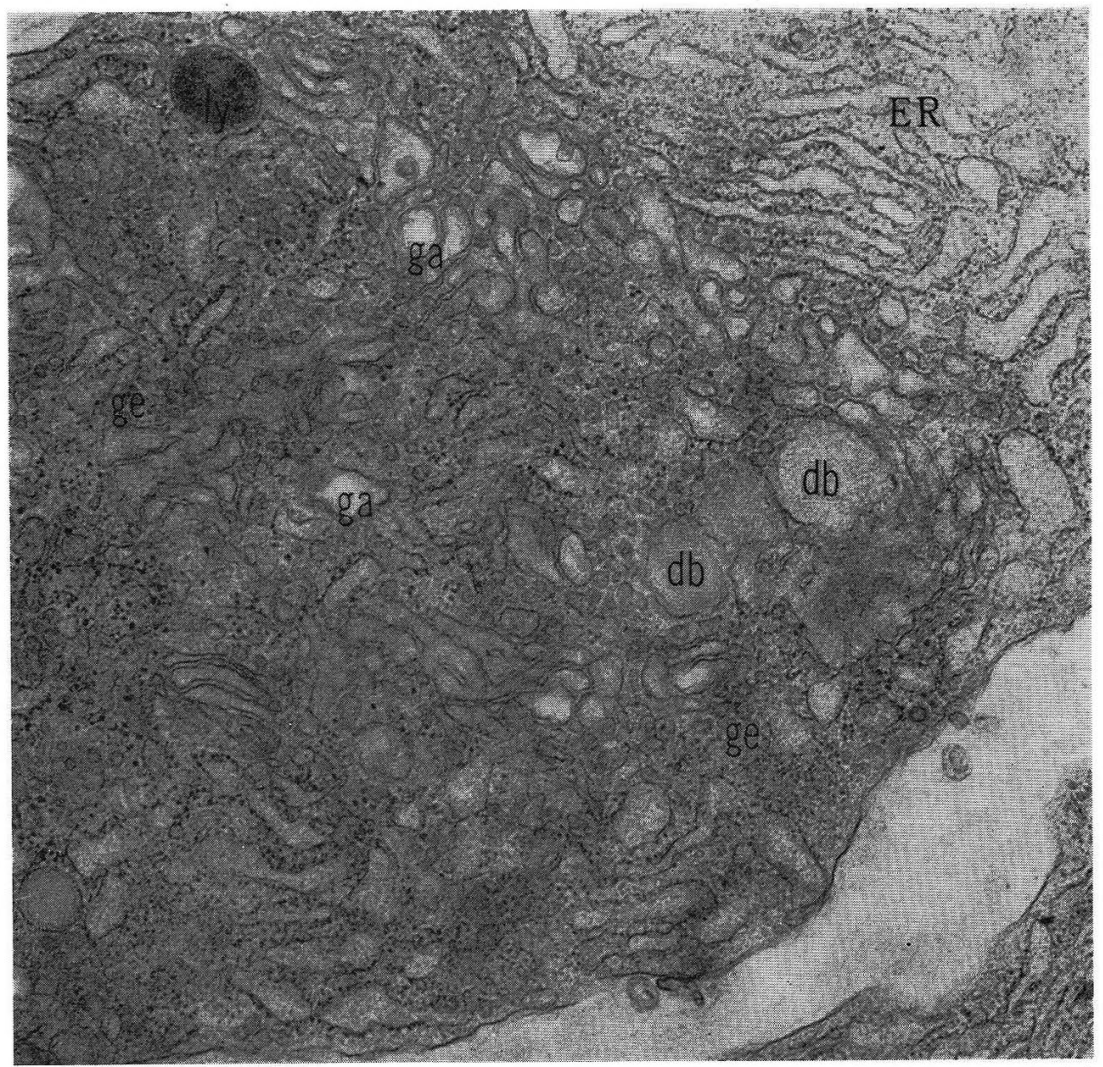

Fig. 21. Golgi apparatus whose lamellae can hardly be distinguished from the Golgi vacuoles $(\mathrm{g} a$ ) as the former are extensively dilated. Some dense bodies of moderate density are seen in the Golgi area. ER ergastoplasm, ge Golgi vesicles, ly an electron opaque dense body composed of the distinct limiting membrane and the dense matrix, between these two elements a narrow, lucent space is present like lysosomes in other cells. $\times 26,700$

diameter, and about $120 \mathrm{~m} / \mathrm{s}$ in inside diameter. Long centrioles, about $800 \mathrm{~m} / \mathrm{in}$ length and having usual diameters, can also be seen (Fig. 23 a). A transverse section of a centriole (Fig. 23 b, inset) reveals that each of nine peripheral tubules or fibers is made up of the so-called triplet fibers, i. e, three subfibers; FAwCETT (1966) called these three, namely the innermost, intermediate and outermost subfibers $\mathrm{A}, \mathrm{B}$ and $\mathrm{C}$ respectively. The three subfibers are closely arrayed in a line, which is oriented not simply radially but obliquely. In a longitudinal section of the centriole the longitudinally cut subfibers of the peripheral tubules measure about $230 \AA$ in diameter (Fig. 2, 18). A tubule found in the Golgi area of a plasma cell illustrated in Figure $23 \mathrm{~b}$, measures about $1 \mu$ in length and about $230 \AA$ in diameter, and probably represents a longitudinally cut subfiber of an unusually long centriole; another centriole of the diplosome is scen in the neighborhood of this subfiber, being cut transversely. Moderately electron dense fibrous structures are protruded radially 

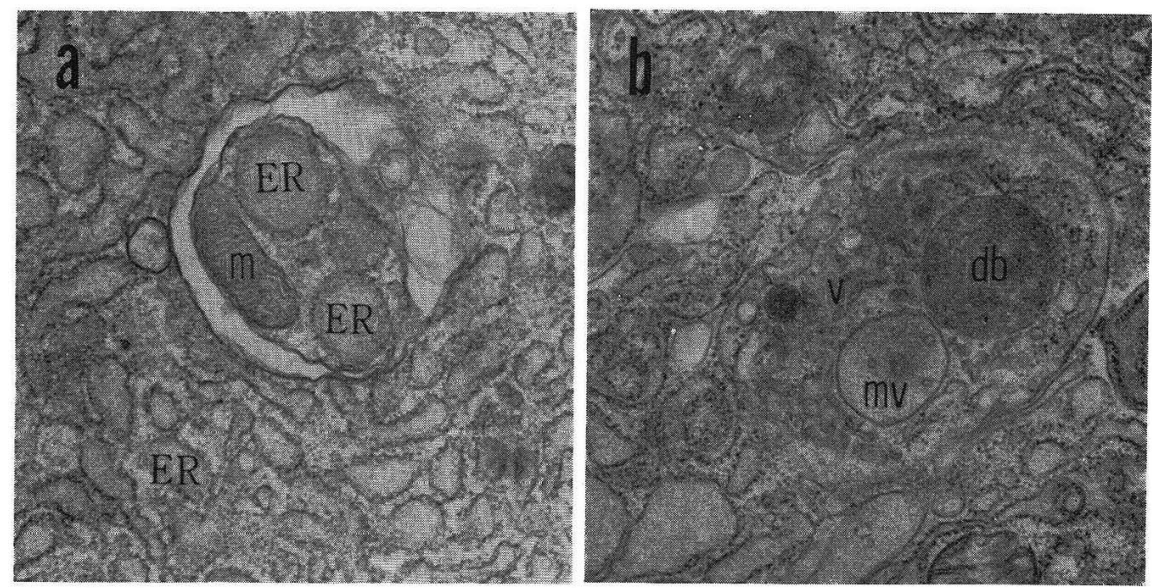

Fig. 22. Gytolysomes. a. A cytolysome containing a mitochondrion $(m)$ and ergastoplasmic sacs $(E R)$ and others. $\times 18,200$. b. A cytolysome containing a dense body $(d b)$, multivesicular body $(m v)$, smooth vesicles $(v)$ and ergastoplasmic sacs as well as free ribosomes. $\times 19,400$
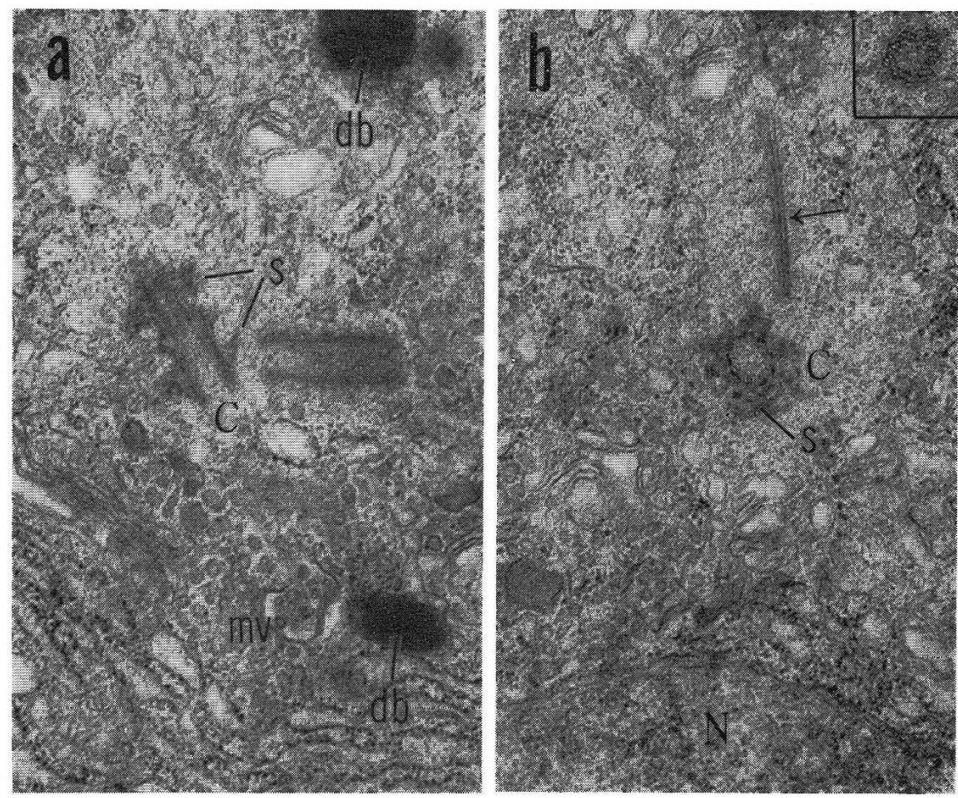

Fig. 23. Diplosomes located within the Golgi area of the plasma cells.

a. Longitudinal section of paired centrioles of a diplosome. The long axes of them cut each other at an angle of about $120^{\circ}$, and one centriole $(C)$ of the diplosome has three satellites $(s)$ paires on each side. The length of the centrioles measures about $800 \mathrm{~m} \mu$, therefore extraordinarily long centrioles. $d b$ electron opaque dense bodies, mv multivesicular body. $\times 18,000$

b. A cross section of one centriole $(C)$ of a diplosome. Rather dense irregular structures around it may probably be satellites (s). A fine tubulus (arrow), measuring about $230 \AA$ in diameter and about $1 \mu$ in length, seen above the centriole may be considered to be a subfiber of the other centriole of the same diplosome. $N$ nucleus. $\times 21,300$

Inset : Cross section of a centriole. Each of 9 peripheral tubuli is represented by so-called triplet fiber consisting of 3 subfibers. $\times 27,000$ 
from the outer surface of some centrioles. They may correspond to the so-called "satellites". As revealed in the longitudinal sections of the centrioles, two (Fig. 18) or three (Fig. 23 a) paired satellites are projected at nearly right angles from the opposite surfaces of the centrioles. Dense irregularly, but almost radially arranged fibrous structures around a transversely sectioned centriole observed in Figure $23 \mathrm{~b}$ seem also to be satellites. It is a noteworthy finding that satellites occur as a rule in one centriole of the diplosome.

Cytoplasmic inclusions: Cytoplasmic inclusion bodies seen in the plasma cells from human nasal polyps can be divided into three kinds : 1) Inclusion bodies in the ergastoplasmic sacs, 2) those bounded by a smooth limiting membrane, and 3) those without a distinct limiting membrane.

1) Inclusion bodies in the ergastoplasmic sacs: In the present study the occurrence of such plasma cells has been sometimes confirmed, in which almost all ergastoplasmic sacs are filled with a dense homogeneous substance and considerably dilated. In a plasma cell illustrated in Figure 12, abundant ergastoplasmic cisternae of this type are closely packed in the entire cytoplasmic area, whereas only a few normal ergastoplasmic sacs remain in the peripheral cytoplasmic zone; free ribosomes

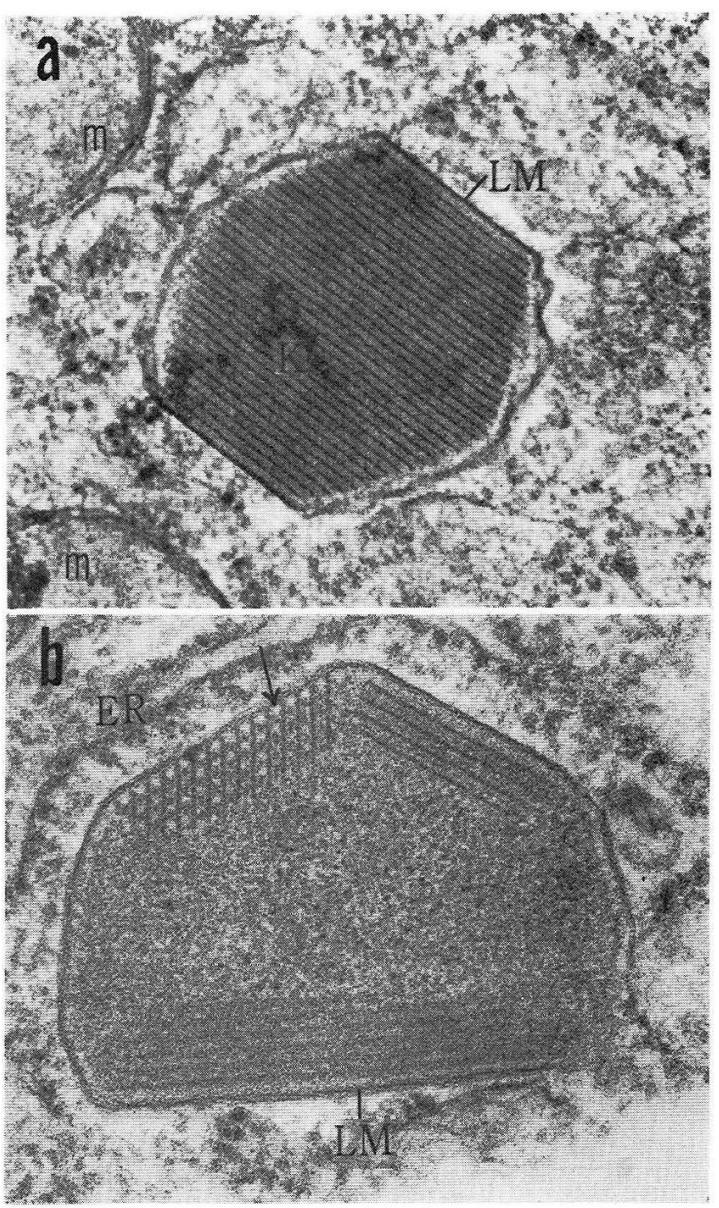

Fig. 24. Grystalloids enclosed in smooth membrane sacs.

a. A hexagonal crystal $(K)$ bounded by a smooth limiting membrane $(L M)$ about $80 \AA$ thick. Closely arranged electron dense striations about $40 \AA$ wide show a periodicity of about $160 \AA$. In the center of the electron lucent zone (about $120 \AA \AA$ in width) between the striations, an indistinct, fine intermediate layer can be seen. $m$ Mitochondria. $\times 60,000$

b. Three crystalline structures bounded by a common smooth limiting membrane $(L M)$. In one of them (arrow) electron dense striations are oriented in two directions. The matrix of the crystal is moderate in density, in which fine granules are dispersed. $E R$ ergastoplasm. $\times 72,000$ are scattered in the narrow cytoplasmic matrix between the dilated cisternae, but mitochondria are almost abscnt; Golgi lamellae are for the most part dilated into Golgi vacuoles; Golgi vesicles are decreased remarkably in number. A plasma cell shown in Figure 13 shows similar changes in the ergastoplasmic sacs. Some of them are extremely enlarged and filled 
with a dense homogeneous substance, whereas numerous others with normal appearance remain in the periphery of the cytoplasm. In the Golgi complex near the nucleus, Golgi lamellae and Golgi vesicles are maintained, though mitochondria are scarcely seen. In general, no clear spaces are recognized between the dense substance and the surrounding ergastoplasmic membrane. This dense homogeneous substance filling the ergastoplasmic sacs probably corresponds to so-called Russell bodies. When many Russell bodies fill up the cytoplasm, the nucleus is strongly pushed away to one side of the cell body. Sometimes a globule of the dense homogeneous material appears in dilated ergastoplasmic sacs and an electron lucent space occurs between the globule and the ergastoplasmic membrane, resembling the socalled intracisternal granules in exocrine cells of the pancreas (Fig. 14, 19). These globules are also considered to be Russell bodies, though they appear generally in small numbers and are encountered only in occasional plasma cells.

In the plasma cells from the nasal polyp, there occur occasionally crystalloid structures enclosed in ergastoplasmic sacs. In the plasma cell illustrated in Figure 15, a Golgi apparatus composed of lamellae and many vesicles, sparse mitochondria and a cytolysome are gathered near the eccentrically located, flattened nucleus. The major part of the cytoplasm is closely packed with numerous transversely oriented, long, slightly curved, spindle-or needle-shaped crystalloid bodies encased one by one in the ergastoplasmic sacs of the same shape. The individual crystalloid bodies extend from one pole of the cell to another; the encasing rough surfaced ergastoplasmic sacs adhere closely to the crystalloids, being connected with each other by several side-branches protruding at right angles from the sacs. A small number of flattened ergastoplasmic sacs remain in the periphery of the cytoplasm. Each spindle-shaped crystalloid body represents the bundle of several closely packed fibrils measuring about $250 \AA$ in width. Each fibril exhibits cross striations running obliquely to the long axis of it, they are repeated with a periodicity of approximately $120 \AA$ (Fig. 16). The cross striations are made up of fine granules about $70 \AA$ in diameter in a row. In the plasma cell seen in Figure 17, there also occur similar crystalloid structures within ergastoplasmic sacs, but they are irregularly arranged and some of them are sectioned transversely; their electron density is somewhat low, and the cross striations are indistinct; the Golgi apparatus of this cell is well preserved, and isolated from the nucleus by the crystalloids.

2) Inclusion bodies bounded by a smooth limiting membrane: A plasma cell illustrated in Figure 24 a contains a nearly hexagonal crystalloid body near the nucleus. It is bounded by a smooth limiting membrane approximately $80 \AA$ thick. Within the crystal, closely packed electron dense striations about $40 \AA$ wide are arranged in parallel lines with a periodicity of about $160 \AA$. Each dense striation is separated by an electron lucent zone about $120 \AA$ wide, in the center of which an indistinct fine intermediate layer is observed. The plasma cell illustrated in Figure 25 a contains two crystalloid bodies, similar to those seen in Figure 24 a, which seem to have fused each other. They exist in the close proximity of the Golgi area and bounded by a common smooth limiting membrane which is partly obscure. One of them is approximately hexagonal in shape, and shows electron dense, closely packed parallel striations repeated with a periodicity of about $160 \AA$, running in two directions which cross each other at an angle of about $60^{\circ}$. This one may probably be identical 
with the crystal as seen in Figure 24 a. Further, two or more crystals of variable shapes and sizes, closely located side by side, can sometimes occur bounded by a common smooth limiting membrane. They possess similar internal periodical structures like the crystal observed in Figure $24 \mathrm{a}$, and are all embedded in the finely
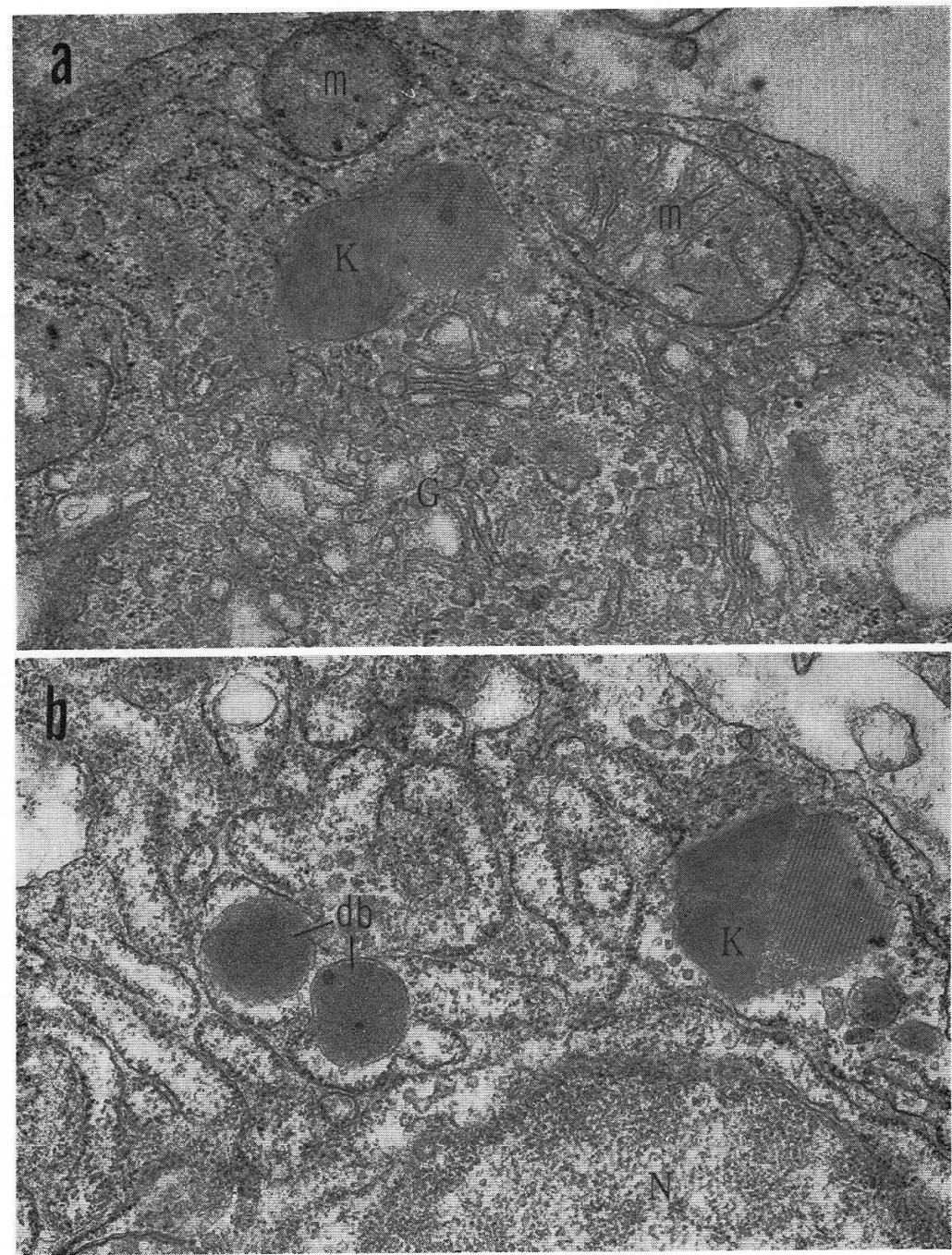

Fig. 25. Crystalloids enclosed in smooth membrane sacs.

a. Two crystalline structures $(K)$ near the Golgi area $(G)$ which are bounded by a common smooth limiting membrane. In the hexagonal one located on the right side the electron dense, parallel striations are oriented in two directions cutting each other at an angle of about $60^{\circ}, m$ Mitochondria. $\times 24,600$

b. In the crystalloid found upper right of the nucleus $(N)$ three similar crystalline structures $(K)$ are enclosed in a common smooth membrane sac. Two smooth membrane bounded dense bodies $(d b)$ seen upper left of the nucleus show faint, indistinct parallel striations suggesting the gradual formation of crystalline structures from dense bodies. $\times 26,500$ 


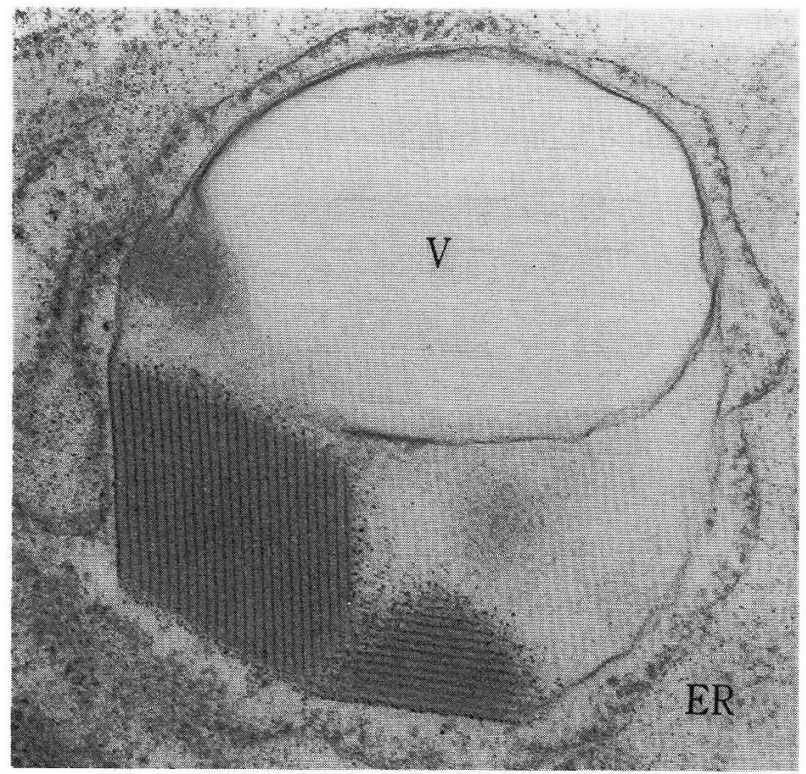

-Fig. 26. Two crystalline structures enclosed together with a large vacuole $(V)$ in a common smooth membrane sac. They show a periodical structure identical with that of the crystal illustrated in Figure $24 \mathrm{a}$. In the electron lucent matrix fine electron dense granules are accumulated along the boundaries of the crystalline structures suggesting the mechanism of the crystal formation. ER ergastoplasm. $\times 47,300$

Fig. 27. Several smooth membrane sacs containing variable numbers of crystalline structures $(K)$, which are embedded in the homogeneous, finely granular matrix of moderate electron density. All crystalline inclusions possess the same periodical structure as described above. ER ergasto$\downarrow$ plasm, $m$ mitochondria. $\times 34,400$

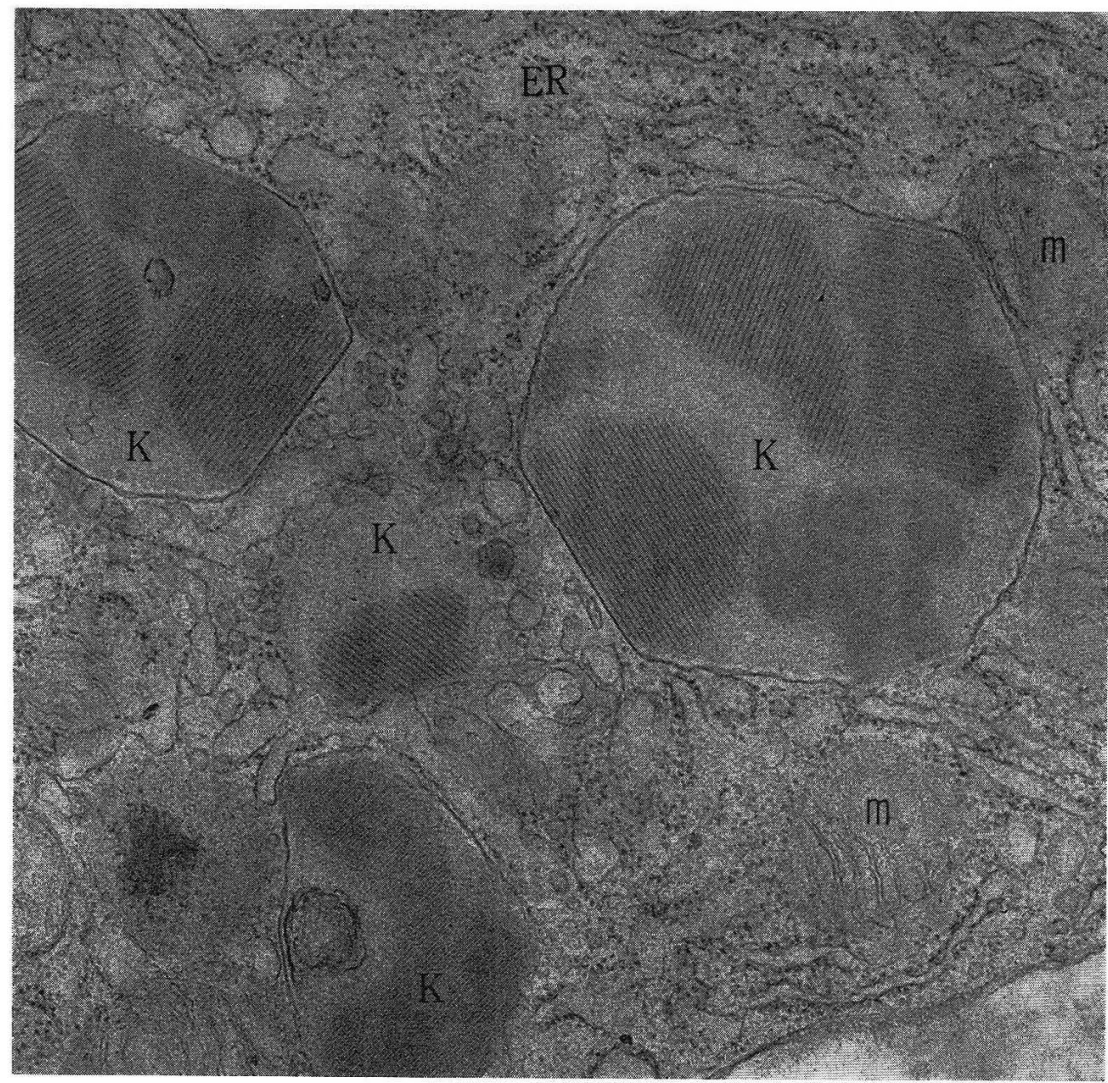


granular matrix of moderate electron density, suggesting that they have crystallized from the matrix substance (Fig. $24 \mathrm{~b}, 25 \mathrm{~b}, 26,27$ ). Occasionally vesicles and vacuoles are found in the matrix of the crystals (Fig. 26, 27). The above mentioned crystalloid bodies bounded by a smooth limiting membrane, may probably be derived from the dense bodies with a moderate electron density, which have been formed in the Golgi apparatus. Two round dense bodies observed in Figure $25 \mathrm{~b}$ are located in the upper left of the nucleus, they are moderately electron-dense and bounded by a smooth
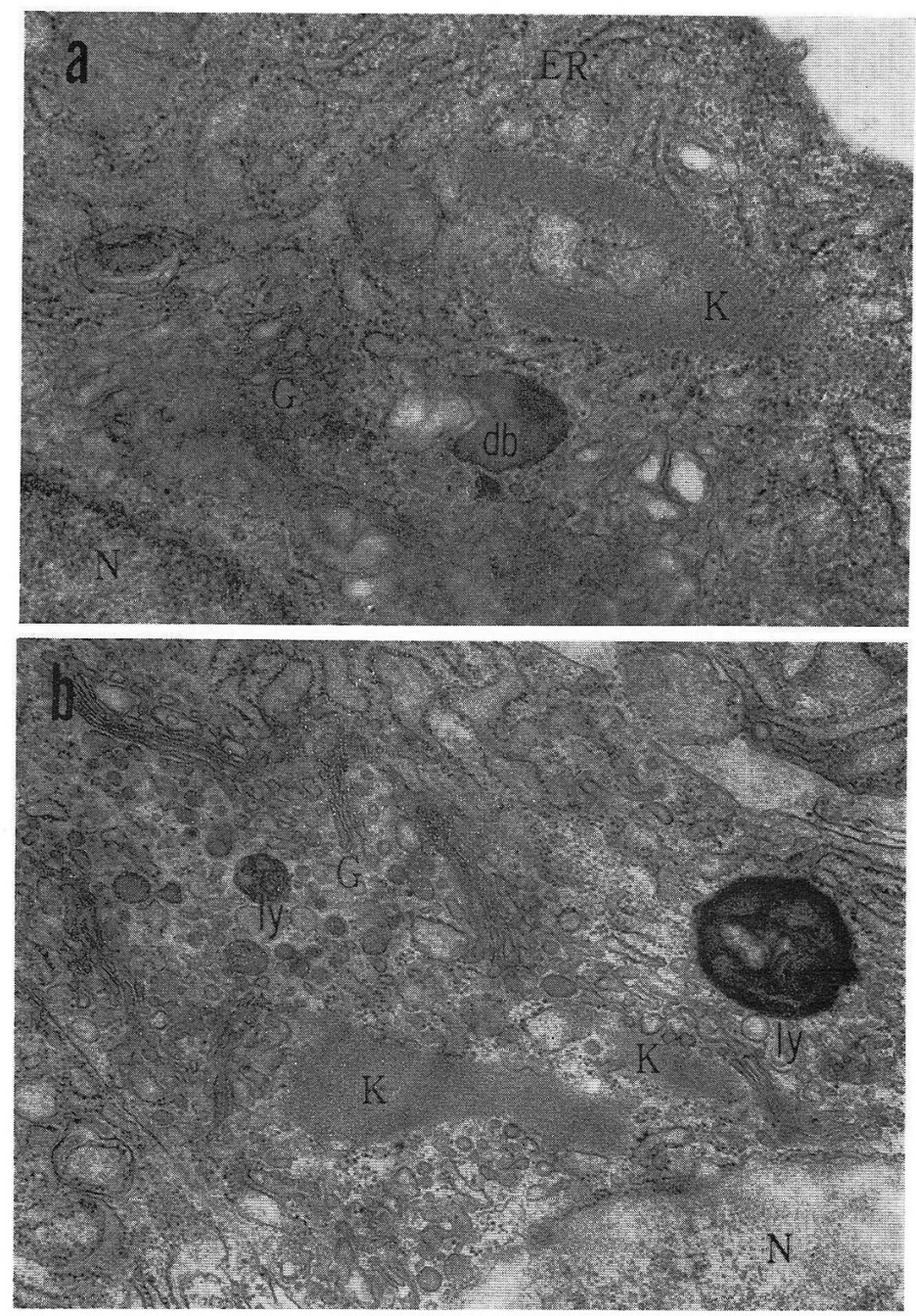

Fig. 28. Rod-shaped crystalloids $(K)$ without a distinct limiting membrane located near (a) and within (b) the Golgi area $(G)$. They are moderate in density exhibiting fine, closely packed fibrillar structures running parallel to their long axes at about $70 \AA$ intervals. $d b$ Dense body, $E R$ ergastoplasm, ly lysosome (dense body) with vesicular and membranous internal structures, $N$ nucleus. $\mathbf{a} \times 24,700 \mathbf{b} \times 20,400$ 
limiting membrane. Their matrix appears finely granular and shows faint and indistinct parallel striations suggesting the gradual formation of crystalloid structures.

3) Inclusion bodies without a distinct limiting membrane: Crystalloids without limiting membrane are occasionally seen outside the ergastoplasm. They are located sometimes within or near the Golgi area (Fig. 28a, b). They are rod-shaped, moderate in density, and exhibit fine fibrillar structures oriented parallel to their long axes, these structures are composed of closely packed fine fibrils of about $60-80 \AA$, running longitudinally at about $70 \AA$ intervals. The fine fibrillar structures however are occasionally partially obscure, and, instead, there occur closely packed fine granules. These crystalloids have no limiting membrane, and are thought to exist directly in the cytoplasmic matrix. The plasma cell illustrated in Figure 29, contains two round

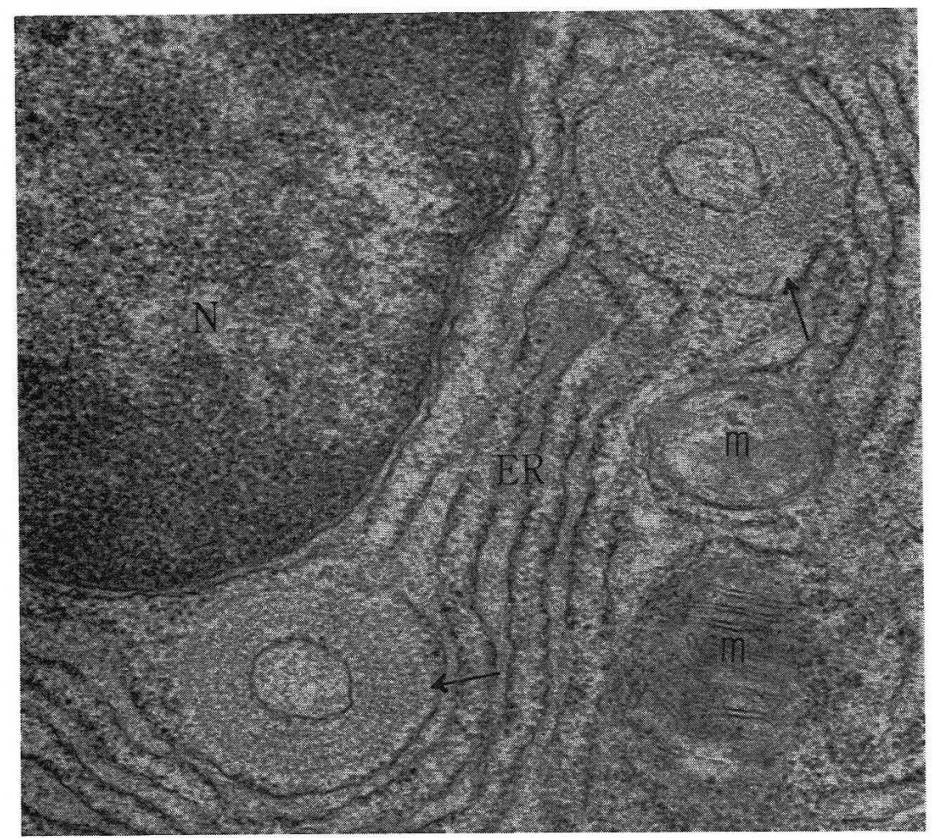

Fig. 29. Two round inclusions (arrow) located in the close vicinity of the nucleus $(N)$. Both of them contain in the center a round ergastoplasmic sac which is surrounded by four membranes of somewhat low density arranged concentrically at regular intervals of about $850 \AA$. Along these membranes fine granules of low density measuring about $80-120 \AA$ in diameter are distributed rather irregularly. $E R$ ergastoplasm, $m$ mitochondria. $\times 36,200$

inclusions in the vicinity of the nucleus. Both are similar in structure, surrounding a round profile of an ergastoplasmic sac in the center, whose ribosomal studs and content are identical with that of the ergastoplasm distributed in other cytoplasmic areas. Around this ergastoplasmic sac four membranes of somewhat low density are arranged concentrically at regular intervals of approximately $850 \AA$. Along these membranes fine granules of low density measuring about $80-120 \AA$ in diameter are distributed rather irregularly. They are smaller and less dense than the ribosomes 
studded on the ergastoplasm. These concentric lamellar structures are not bounded by the limiting membrane, and along their outer surface flattened ergastoplasmic sacs are closely arranged. Because of the lack of the limiting membrane, they are included in this category of the inclusion bodies. Probably these rare inclusion bodies have been derived from ergastoplasmic sacs arranged in concentric lamellar patterns.

\section{Discussion}

As to the distribution of the plasma cells, Watanabe et al. (1956) reported in the tissue from the portio erosion, that they generally occur solitarily but sometimes in groups. Movat and Fernando (1962), however, said that both in lymph nodes and in connective tissue of hamsters and rabbits, they are found more frequently in groups than singly, and that in the connective tissue a perivascular distribution predominates. In the present study, it has been proved that the plasma cells show tendency to be gathered in the perivascular region as demonstrated by Movat and FERNANDO, and that they occur singly or make small groups as reported by WATANABE et al. As to the shape of the plasma cells, it has been confirmed that they are round or elliptic when they exist singly, but irregular when in groups, as described by Watanabe et al. and Movat and Fernando. Microvillus-like processes protruded from the cell surface were frequently seen. According to Movat and Fernando, they might be concerned with the uptake of substances into plasma cells, however, any evidence to support this view has not been obtained in the present observation.

In accordance with reports by many workers (DoHI et al. 1956, WATANABE et al. 1956, Movat and Fernando 1962, etc.), the nucleus of the plasma cells is round or elliptic in shape, located eccentrically, and contains several large, electron dense, polymorphous chromatin masses arranged regularly along the nuclear membrane, exhibiting the appearance of so-called "Radkern". "According to DoHr et al. (1956), these chromatin masses may be made up from the accumulation of entangled helical chromosomal filaments, which are again composed of chromatin subfibers. The present observation has confirmed this description; the above mentioned highly dense chromatin masses may correspond to the so-called heterochromatin, and be composed of closely packed minute chromatin granules and chromatin fibrils. The chromatin granules measure about $170 \AA$, nearly in agreement with the value (20 $m \mu$ ) given by WATANABE et al. (1956), and the chromatin fibrils measure about $50 \AA$ in diameter. Movat and Fernando (1962) reported that the outer nuclear membrane studded with ribosomes is occasionally continuous to ergastoplamic sacs. This, however, has not been confirmed by the present observation, though it has been proved that the outer membrane may form, sac-shaped extrusions into the cytoplasm. In the present study a dense homogeneous material has been observed in the extensively distended portion of the perinuclear spaces. Its nature and significance have not been clarified. Although Braunsteiner et al. (1953) recognized in human bone marrow plasma cells with several nucleoli, the plasma cells observed in the present study contain generally one, and only occasionally two nucleolei. In the nucleolus of the plasma cells from the nasal polyps, the manifestation of the nucleolonema structure is usually not prominent.

Stockinger (1962), Brittin et al. (1963), and Gadrat et al. (1963), in their 
electron microscopic studies on the bone marrows from patients with macroglobulinemia or dysglobulinemia, described nuclear inclusion bodies, closely resembling those in the present observations. According to Stockinger, they vary in electron density and size and are bounded usually by a single, but occasionally by a double limiting membrane. According to BritTin et al., they are round or elliptic in shape, always located in the center of the nucleus, and covered with a limiting membrane about $70 \AA$ thick; their content consists of an amorphous substance of low density and dense osmiophilic spherules with a perfectly smooth margin. The nuclear inclusions, observed in the present study, nearly agree in several morphological characteristics with those described by BRITTIN et al., namely, they were nearly round in shape, having finely granular, homogeneously compact and moderately dense matrices which are occasionally somewhat unhomogeneous or contain numerous electron dense granules with diameter of approximately $570 \AA$ distributed throughout the matrix exhibiting a net-like arrangement. The indistinct limiting membrane is single, but partially double ; the inner membrane can invaginate toward the interior to form invaginated vesicles in the matrix. When the nuclear inclusion appears singly, it is located nearly in the center of the nucleus as reported by BRITTIN et al.; but when two inclusions occur, they are not always found in the center. The nuclear vacuoles observed by THIÉRy (1957) in the plasma cells from rat and mouse lymph nodes may probably be identical with the above described nuclear inclusions found in the plasma cells from the human nasal polyps. He said that the nuclear vacuole will discharge its content outside the cell. In the present study the author has confirmed the finding that the nuclear inclusion adheres with its limiting membrane to the nuclear membrane. The hypotheses of THIÉRY, therefore, can not be wholly denied as quite unplausible. Paraskevas et al. (1961) and Brittin et al. (1963) were of opinion that nuclear inclusions, when accumulated too much, will impede cell metabolism ; BRITTIN et al. (1963) assumed that they will synthesize other proteins than nucleoproteins, since they contain proteins though not DNA and RNA. The author can not at once accept this view of PARAskevas et al. and BRITTIN et al., because he have not been able to demonstrate any particular morphological changes in the ergastoplasm, Golgi apparatus and mitochondria of plasma cells which contain the nuclear inclusions. It was impossible in the present study to clarify the formation mechanism of the nuclear inclusions, the biochemical composition of their contents, and their significance.

Many light microscopic studies have revealed that the cytoplasm of the plasma cell is intensely basophilic and metachromatic, containing a large amount of RNA. Braunsteiner et al. (1953, 1955) have demonstrated for the first time by electron microscopy a large amount of the rough surfaced endoplasmic reticulum in the plasma cells of the human bone marrows. This was later confirmed by TANAKA (1956), Wellensiek (1957), Thiéry (1958, 1960), Movat and Wilson (1959), Bessis (1961), and Movat and Fernando (1962). According to Movat and Fernando (1962), the ergastoplasm is developed more highly in plasma cells than in other mesenchymal cells, and occupy nearly the entire cytoplasm up to its margin without leaving there an unoccupied clear peripheral zone as that seen in fibroblasts. Also in the plasma cells found in the nasal polyp, the well-developed ergastoplasmic elements are compactly distributed in the whole cytoplasm except for the Golgi 
area, filling it up to the cytoplasmic layer near the cell boundary. In general, they appear as elongated flattened sacs bounded by the limiting membrane which are for the most part arranged parallel with each other to exhibit a lamellar pattern. The ergastoplasm of the plasma cells of the human nasal polyp can be classified into the following four types: 1) In the first, most frequent type, the flattened sacs with narrow and uniform lumina are arranged very regularly in parallel lines showing a typical lamellar pattern. 2) In the second type, the lumina of the elongated flattened sacs show in some parts small inconspicuous dilatations so that the width of the sacs becomes variable, and the parallel pattern of them becomes more or less irregular. 3) In the third type, the dilatations of the sacs are so prominent, that they are all transformed into cisternae ; the lamellar pattern of the ergastoplasm is obscure. 4) In the fourth type, the lamellar array of the elongated flattened sacs becomes partially obscure owing to the conspicuous local dilatations of the lumina. Ribosomes attached to the outer surface of the limiting membrane measure about 150-200 A in diameter in agreement with reports by WATANABE et al. (1956), WeLSH (1960), and Tokumaru (1963). The finding of Movat and Fernando (1962) that the arrangement of the ribosomes on the membrane was not uniform has been confirmed in the present observation; they are most frequently arranged in ring form, but sometimes in rosette or spiral form. The content of the ergastoplasmic sacs shows variable electron density as reported by DEANE (1964). In the majority of cases, they contain a floccular substance in accordance with findings by Movat and Fernando (1962) and by Moe (1964), which appear either densely homogeneous or loosely unhomogeneous. Bernhard and Granboulan (1960) and Bessis (1964) thought that the ergastoplasmic sacs are in general flattened in the immature plasma cells but they are distended gradually as the plasma cells become mature. However, the present study has revealed that the ergastoplasmic sacs show morphological variety as stated by Movat and FERnANDo (1962), and on the basis of the present observation the author has actually classified the four types. But the author failed to find any definite relations between these morphological varieties of the ergastoplasmic sacs and the characteristics of their content. The questions as to what type may suggest hyperfunction of the ergastoplasm and what type hypofunction could not be answered in the scope of the present study. On the basis of the generally accepted knowledge, it seems at least certain that the highly developed ergastoplasm in the plasma cells indicates a vigorous protein synthesis in them, and that the ribosome is the site of the synthesis of proteins including antibodies ( $\gamma$-globulin), and the ergastoplasmic sac is the site of storage of the synthesized proteins.

Maximow (1930, refer to Iто et al. 1938) assumed that the "heller Plasmahof", which is identified by light microscopy adjacent to the nucleus of the plasma cells, may likely be the negative image of the Golgi apparatus. Ito et al. (1938) demonstrated for the first time the Golgi apparatus of the plasma cell by Kolatchev's method in the human lacrimal gland and other tissues and confirmed the postulation of MAximow. As revealed even with light microscope, the plasma cells possess in comparison with other mesenchymal cells the most highly developed large Golgi apparatus. By electron microscopy, WAtANABE et al. (1956) demonstrated for the first time the Golgi apparatus of the plasma cell which consisted of granules or vesicles, vacuoles and lamellae, and this was confirmed by Stoeckenius (1957 a), 
Wellensiek (1957) and Thiéry (1960). Movat and Fernando (1962) proposed on the basis of the findings obtained by electron microscopy that the Golgi apparatus, was best developed in the plasma cells and fibroblasts among mesenchymal cells. Also in the plasma cells from human nasal polyps observed in the present study, a large Golgi apparatus was demonstrated with its conspicuous lamellae and numerous vesicles. On the contrary, such Golgi apparatus, in which, as described by BERNHARD and GRANBoulan (1960), vesicles and vacuoles predominate over poorly developed Golgi lamellae, is rare. Golgi lamellae in their beautiful lamellar pattern are gently curved, and, as described by Movat and Fernando (1962), run along the boundary of the Golgi area to surround it discontinuously. In some parts, they also extend toward the interior of the Golgi area forming a network as a whole. The end parts of the flattened sacs of the lamellae make frequently cisternal distensions. The electron density of the content of the Golgi lamellae is in general fairly high, Golgi vacuoles $(100-400 \mathrm{~m} \mu)$ are scarce in plasma cells of the nasal polyp and contain always electron lucent substance. Findings suggesting their origin from the terminal distensions of the Golgi lamellae are frequently obtained. Pictures are also encountered which suggest that not only the terminal portion of, but also a whole flattened sac of the Golgi lamella may distend into a Golgi vacuole. Abundant Golgi vesicles $(70-240 \mathrm{~m} \mu)$ are mainly accumulated along the Golgi lamella. The postulation that the vesicles closely aligned in a row fuse with each other to form the lamella is supported by the findings in the present study. As to the origin of the Golgi vesicles, it is necessary to consider the relation between the ergastoplasmic sacs and the Golgi apparatus. Especially in the proximity of the Golgi area, smooth surfaced blebs often protrude from the rough limiting membrane of the ergastoplasmic sacs, suggesting that these blebs might be pinched off to form smooth surfaced vesicles containing an electron dense substance. These vesicles might probably migrate toward the Golgi area and accumulate as Golgi vesicles. Against this view, MoE (1964) assumed that the Golgi vesicles may be derived from the Golgi lamellae. Considering all these morphological findings, the author, in accordance with Hirsar (1963) and Serine (1966), wants to propose the following hypothesis with regard to the formation of the end product (antibody) of the plasma cell. Proteins, synthesized by ribosomes and stored in ergastoplasmic sacs, may be transported, by means of smooth surfaced vesicles derived from the ergastoplasmic sacs, to the Golgi apparatus, to be contained in the Golgi vesicles; they may be further transported into the Golgi lamellae by fusion of the vesicles and finally into the Golgi vacuoles derived from the lamellae; the proteins may undergo some changes while passing through the Golgi apparatus, becoming the end product contained in the Golgi vacuoles. In the present study, however, little information has been acquired which could indicate the fate of these vacuoles. In rare plasma cells the smooth membrane bound vacuoles, which may probably correspond to the Golgi vacuoles, are observed in the peripheral cytoplasmic part, and some of them occur near the surface plasma membrane suggesting the possibility of an extracellular discharge of the vacuole content. This hypothesis may be supported by the fact that in the plasma cells, conspicuously developed ergastoplasm and the Golgi apparatus are coupled. BEssis (1964) stated that in plasma cells proteins may either be synthesized in the ergastoplasm to be stored in Golgi vacuoles and discharged outside the 
cell, or be conversely synthesized in the Golgi apparatus to be stored in the ergastoplasm. The latter possibility, however, seems to be contradictory to the generally accepted concept of today. Also it is not inconceivable that proteins stored in the ergastoplasmic sacs may directly be discharged into the extracellular space; in such a view, however, the role of the Golgi apparatus will remain unelucidated.

The description by Movat and Fernando (1962) that the plasma cells have more numerous mitochondria than any other mesenchymal cells has been wholly confirmed in the present study. According to BERnhard and Granboulan (1960), in the plasma cells from several organs and tissues of the mouse, rabbit and man, mitochondria are always closely linked with the ergastoplasmic membrane. In the present observation the same finding has been revealed in the plasma cells from the human nasal polyp, because of the close disposition of the mitochondria adjacent to the compact array of the ergastoplasmic sacs, the ergastoplasmic membranes which are closely arrayed parallel to the surface of the mitochondria, have been not infrequently observed. THIÉRY (1960) assumed that the mitochondria became smaller as the maturation of the plasma cells proceeded, but it seems to need utmost deliberation to detect the minute difference in the size of the mitochondria in ultrathin sections. In the present observation, it has been proved for the first time the occurrence of the intramitochondrial granules $(35-55 \mathrm{~m} \mu)$ also in the plasma cells. They appear in considerable frequency and it has been revealed that they consist of still more minute subunits.

Many workers observed with light microscope the centrioles of the plasma cells, especially Iто et al. (1938) demonstrated the diplosome in the center of the Golgi area of the human plasma cells. In their electron microscopic study on the mouse lymph nodes, TANAKA et al. (1957) observed the diplosomes of the plasma cell, proving that they represent cylinders measuring about $350 \mathrm{~m} \mu$ in length and about $120-160 \mathrm{~m} \mu$ and about $70 \mathrm{~m} \mu$ in outside and inside diameters respectively. Further, they could reveal nine tubules measuring about $20 \mathrm{~m} \mu$ in thickness arranged longitudinally at uniform intervals in the electron dense wall of the cylinders. According to their observation, the long axes of paired centrioles of the diplosome crossed at varying angles. Movat and FERnANDo (1962), in the rabbit and hamster, and Bessis (1964), in man, confirmed that the centrioles of the plasma cells possess the same structure as those of other cells. In the present investigation on the plasma cells from the human nasal polyp, the diplosome has been demonstrated in the central rcgion of the Golgi area. The long axes of the paired centrioles were directed to cut each other at rectangle or at angles of variable degrees as described by TANAKA et al. (1957). The centriolar cylinders of the plasma cells from human nasal polyp measure about $470 \mathrm{~m} \mu$ in length, about $210 \mathrm{~m} \mu$ in outside diameter, and about $120 \mathrm{~m} \mu$ in inside diameter, slightly larger than the values proposed by TANAKA et al., and approximately equal to those reported by Stoeckenius (1957 a), MAziA (1961), and FAwGetT (1966). FAwGETT frequently observed long centrioles in chick sperm cells. Also in plasma cells of the nasal polyp, the author has observed extremely long centrioles measuring about $800 \mathrm{~m} \mu$ in length which, however, possess the thickness or diameter of the ordinary value. Bessis and THIÉRy (1961) and Bessis (1964) found, in leukocytes, centrioles with two satellites and FAwcETT (1966) reported those with two or more satellites. In the present observation it has been revealed 
that the majority of centrioles of the plasma cells possess two pairs of satellites which protrude from both lateral sides of the longitudinally sectioned cylinders but occasionally three pairs. It is worthy of notice that the satellites have been demonstrated exclusively in one of the paired centrioles of a diplosome.

In cytoplasm of the plasma cell, especially within and around the Golgi area, there occur, at a considerably high frequency, round or elliptic, homogeneously dense bodies bounded by a smooth limiting membrane. Though the activity of the acid phosphatase has not been examined, they might probably correspond to the lysosome discovered by Novikoff (1961), Movat and Fernando (1962) also observed similar bodies in the plasma cells of the rabbit and hamster, and described them as dense bodies. The lysosomes which have been identified in the plasma cells of the human nasal polyp should be classified according to the degree of the electron density of the matrix into the following three categories, namely into those with moderate density, with rather high density and with very high density. These lysosomes with a variety of appearance may possibly be formed by the fusion of electron dense Golgi vesicles in the Golgi area. Kurosumi (1965) maintained in his review on the lysosome that he can not deny the origin of the lysosomes from the Golgi complex, since the components of the Golgi apparatus, especially Golgi vesicles are positive for acid phosphatase activity test. Besides these homogeneously dense lysosomes mentioned above, there occur in plasma cells of the nasal polyp rarely dense bodies containing in their matrix vesicles, vacuoles, dense membranous structures and myelin figures, which resemble those described by Movat and FerNANDO (1962). These dense bodies with various internal structures are considered to belong to the lysosomes. Furthermore, the cytolysomes known since Novikoff and EssNer (1962) has been described in the plasma cell for the first time; they may occur in varying sites, are rather large in size (about $1.0-1.8 \mu$ ) and bounded by a smooth limiting membrane; they contain degenerated mitochondria, ergastoplasmic sacs and multivesicular bodies. Presumably they would encompass the degenerated portions of the cytoplasm in the limiting membrane to isolate them from the healthy part and thereafter digest them gradually by means of the hydrolytic enzymes which a cytolysome should contain. The above mentioned rare lysosomes containing various internal structures may probably have been derived from the cytolysomes and be regarded as aged cytolysomes. The question whether the cytolysomes of the plasma cells will be released into the extracellular space or not, was not answered. As for the relation between the lysosome and the cytolysome, Ashford and Porter (1962), Gonfer and Stenger (1964) and Serine (1966) proposed that the former might be derived from the latter. The author, however, is of the opinion on the basis of the above findings that there are two kinds of lysosome in the plasma cells, one of which may have been derived from the cytolysome.

Since the first description by Russell (1890) abundant light microscopic observations on the Russell body have been reported (KLIEN 1892 and Touton 1893, (both cited by Kinugawa 1928), Kinugawa 1928, Pearse 1949, White 1954, Ortega 1957, Guzman 1962). Electron microscopic observations on this body were made by Dohi et al. (1956), Wellensiek (1957), Stoegrenius (1957 b), Thiéry (1958), Welsh (1960) and Movat and Fernando (1962). As for the origin of the Russell body, DoHr et al. (1956) considered it to be derived partly from the mitochondria and partly 
from the ergastoplasm, and Guzman (1962) likewise assumed that degeneration and swelling of the mitochondria may result in the Russell body. THIÉRY (1960), however, disapproved the mitochondrial origin. According to Stoegrenius (1957 b), Thiéry (1960), Welsh (1960) and Movat and Fernando (1962), Russell bodies may be produced in the ergastoplasm. Various views have been proposed concerning the signi ficance of the Russell body. Pearse (1949) regarded it as a form of degeneration of the plasma cell. Some considered it as an antibody stored in the cell (Amano 1958). According to Stobвe (1962), the Russell bodies are extruded from the cell after disruption of the plasma cells remain as spherical masses in the chronic inflammatory tissue and presumably serve as an antibody depot. In the present observation, the plasma cells containing Russell bodies are found only rarely in the connective tissue of the nasal polyp, these bodies occur always in ergastoplasmic sacs. The author has classified them into two types. In one type, the homogeneous, electron dense substances, as described by THIÉRY (1960), fill up the dilated ergastoplasmic sacs and form numerous round or elliptic bodies which occupy the entire cytoplasm. As a result the normal ergastoplasmic sacs and mitochondria almost disappear and also the Golgi apparatus is affected. In this type there occurs no clear space between the ergastoplasmic membrane and the dense homogeneous content, the former being applied closely on the latter. It may be assumed that the Russell bodies may have resulted from the accumulation and the condensation of the protein in the ergastoplasmic sacs, which may have been caused by dysfunction in the plasma cell. As above mentioned, the mitochondria become almost completely invisible, but there are no indications that they have been transformed into the Russell bodies. In the second type, the spherical, dense, homogeneous material appears in the dilated ergastoplasmic sacs leaving a clear space of considerable width between it and the ergastoplasmic membrane. This resembles the well-known intracisternal granules in the exocrine cells of the pancreas (Iснікаwa 1965, etc.). The plasma cells with this type of Russell bodies which may be encountered only rarely in the nasal polyps exhibit no change in cell organelles. It seems clear that Russell bodies in the plasma cells of the nasal polyp arise in the ergastoplasmic sacs and consist of proteins elaborated and accumulated in them. On the other hand no data has been obtained on the basis of which the significance of the Russell bodies may be discussed, except for the above mentioned finding suggesting the dysfunction of the cell as a cause of genesis of the bodies. Only a small part of plasma cells in the nasal polyp observed contained Russell bodies and subsequently the present material seems not very appropriate for the investigation of Russell bodies. To elucidate several problems concerning the Russell bodies, further electron microscope studies in other materials are necessary.

It is of interest that in the plasma cells of the human nasal polyp there have occurred by far more numerous crystalline structrues than in those of other tissues and animals examined until today. Owing to the present observation they have been classified into three types: 1) those found in ergastoplasmic sacs, 2) those bounded by a smooth limiting membrane, and 3) those without a distinct limiting membrane. The crystalloid structures found in ergastoplasmic sacs were noted already by Wellensiek (1957), Thiéry (1958) and Movat and Fernando (1962) in the animal plasma cells. The present report seems to be the first concerning the first 
type of the crystalloid in the human plasma cells. This is also the case with other types of the crystalloids.

The crystalloids found in ergastoplasmic sacs are elongated spindle-or needleshaped structures with high electron density. Each spindle is composed of parallel fibers about $250 \AA$ in thickness, which have cross striations about $70 \AA$ in width, running rather obliquely to the long axes of the fibers and showing periodicity of about $120 \AA$ A. Each striation consists of minute granules. This ultrastructure agrees approximately with those reported by WELLENSIEK (1957) and others. These relatively rare, spindle-shaped inclusion bodies have probable been derived from protein stored in the ergastoplasmic sacs.

The crystalline bodies bounded by smooth limiting membrane are observed at fairly high frequency, mainly adjacent to the Golgi area. The polygonal crystals contained in these bodies show striations about $40 \AA$ wide, arranged in parallel lines with periodicity of about $160 \AA$; they occasionally show dense striations oriented in two directions which cross each other at an angle of about $60^{\circ}$. The matrix of the bodies is of medium electron density and finely granular in appearance. It exhibits findings which may suggest that the fine granules closely and regularly arranged in rows make gradually striations. The crystal structures are thus believed to be formed from the periphery toward the interior of the body. Occasionally vesicles and vacuoles occur in the matrix. These crystal structures bounded by the smooth limiting membrane is probably derived from the dense bodies with medium electron density which have been formed in the Golgi apparatus, since there exist transitional forms between the crystals and the dense bodies. As afore mentioned, the dense body is considered to contain proteins, since it is presumably formed by the fusion of the Golgi vesicles which may be derived from smooth surfaced vesicles originated from the ergastoplasmic sacs. Thus, these crystals are postulated to be protein crystals. It is worthy of note that the Golgi vesicles may, on the one hand, turn into the Golgi lamellae and then into the Golgi vacuoles to elaborate the end product of the plasma cell, while on the other hand they may fuse into the dense bodies which should play a role as lysosomes, and occasionally may be transformed into crystals.

The third variety - the rod-shaped crystalloid structure without a distinct limiting membrane - is rarely observed in or around the Golgi area. This is composed of closely packed striations or filaments, about $60-80 \AA$ thick, running parallel to the long axis at uniform intervals of about $70 \AA$. The origin of this structure is perfectly obscure.

Though the crystalline structures occur, as mentioned above, fairly frequently in the cytoplasm of the plasma cells from the human nasal polyp, their significance and fate remain unelucidated in the present study.

The round inclusion bodies with a concentric lamellar structure found in one plasma cell was assumed to have been derived from degenerated portions of the ergastoplasm. Their significance, however, was perfectly unclear.

As for antibody, investigations by many workers have established the hypotheses that the plasma cell is the very source of it (Dohr et al. 1944, 1956, FAgraeus 1948, Braunsteiner and Pakesch 1955, Coons et al. 1955, Ortega 1957, Amano 1958, Nossal 1958, Nossal and Mäkelä 1962, Petris and Karlsbad 1965, Glark 1966). Petris and Karlsbad (1965) postulated that the antibody is synthesized by ribo- 
somes, especially by those studded on the ergastoplasmic membranes, and condensed in the ergastoplasmic sacs. CLARK (1966) stated that in the latent period of secretion, the antibody elaborated in the ergastoplasmic sacs would be transferred to the Golgi apparatus, but the role of the Golgi apparatus played in the antibody secretion was not clarified. ORTEGA (1957) observed by means of the fluorescent antibody technique that the release of the $\gamma$-globulin from the plasma cells might be carried out both by the holocrine and apocrine mechanism. But up to date none have elucidated morphologically how the antibody is synthesized in the plasma cells and how it is discharged out of these cells. Also in the present experiment the mechanism of antibody production in the plasma cell could not be sufficiently elucidated. Since, however, electron dense materials are often demonstrated in the ergastoplasmic sacs and the Golgi complex, the author assumes, with Petris and Karlsbed, that the antibody will be elaborated by ribosomes studded on the ergastoplasmic membrane and after being deposited in the ergastoplasm, will be transported to the Golgi apparatus to be condensed there. The occurrence, though rare, of plasma cells which contain in the peripheral cytoplasm numerous vacuoles bounded by a smooth limiting membrane like the Golgi vacuoles seems to suggest that the antibody which has been elaborated in the Golgi apparatus will be enclosed in the smooth limiting membrane (Golgi vacuoles) and in this state will migrate to the periphery of the cell to be discharged outside.

\section{Summary}

1. In the subepithelial connective tissue of the human nasal polyp, there occurred many plasma cells scattered singly or, occasionally, in small groups. Their shape was variable and showed large cytoplasmic projections containing ergastoplasmic sacs, as well as microvillus-like processes. The basement membrane, if recognizable, was never continuous all around the cell surface. A pinocytotic figure was rarely seen.

2. The nucleus, usually eccentrically placed, was characterized by the accumulation of chromatin masses beneath the nuclear envelop ("Radkern"). Spherical nuclear inclusions were occasionally recognized; they were bounded by a smooth, partially double limiting membrane and contained a moderately electron dense matrix, in which electron-dense granules were occasionally observed.

3. The cytoplasm of the plasma cells was filled up, except for the Golgi area, with well-developed abundant ergastoplasmic sacs. They were represented mainly by flattened sacs closely packed in a lamellar pattern. Though they varied considerably in shape and in property of the content, it was difficult to estimate functional states of a plasma cell from the morphological aspects of the ergastoplasm. Smooth membrane-bounded electron dense vesicles detached from the ergastoplasmic sacs, especially from those present near the Golgi area, to join Golgi vesicles. The ribosomes were irregularly attached to the ergastoplasmic membrane and showed often ring-, and occasionally rosette- or spiral-shaped array. Free ribosomes occurred in small numbers.

4. The large Golgi apparatus near the nucleus was composed of well-developed 
lamellae, numerous vesicles and a few vacuoles. The lamellae and vesicles contained frequently dense meterials. The Golgi vacuoles contained usually less dense substance and were assumed to be derived from distensions in the Golgi lamellae.

5. Mitochondria gathered near the nucleus, especially around the Golgi area. Intramitochondrial granules $(35-55 \mathrm{~m} \mu)$ were frequently found in their matrix.

6. The diplosome of the plasma cell was revealed within the Golgi area; the arrangement of the fibers or tubuli in the centriolar cylinder was in a 9 triplets +0 pattern. The long axes of the paired centrioles crossed each other at an angle rather greater than $90^{\circ}$. The satellites were identified exclusively in one of the paired centrioles of the diplosome.

7. Dense bodies, i. e. lysosomes occurred in a fairly large number. The majority of them contained a homogeneous, electron-dense matrix and were usually located in or around the Golgi area. A few dense bodies showed various internal structures. The dense bodies of the former type were believed to result from fusion of the Golgi vesicles, whereas those of the latter type were considered as aged cytolysomes. Cytolysomes bounded by a limiting membrane and containing degenerated ergastoplasmic sacs, mitochondria and multivesiclular bodies were rarely recognized.

8. Russell bodies were identified only in a few plasma cells. They were all bounded by the ergastoplasmic membranes and thought to be derived from proteins accumulated in the ergastoplasm. They were classified into two types: In one type, the dilated ergastoplasmic sacs were filled up with a homogeneous electron-dense substance to which the ergastoplasmic membranes were closely applied leaving no space. In the other type, electron-dense spherical granules occurred in dilated ergastoplasmic sacs showing the clear space between the granules and the limiting membranes as in the intracistenal granules in exocrine pancreas cells.

9. Crystalline structures in the cytoplasm occurred frequently. They were classified into 1) needle- or spindle-shaped structures found in the ergastoplasmic sac; 2) polygonal crystals bounded by a smooth limiting membrane which were found most frequently in this study; and 3) rod-shaped ones without a distinct limiting membrane. All these types seemed to correspond to the different forms of proteins.

10. The mechanism of the antibody production in the plasma cell was discussed.

Acknowledgement. The author is deeply grateful to Prof. H. IsHIr, Chairman of the Department of Oto-rhino-laryngology, who has given him guidance throughout this work and kindly reviewed the manuscript. He is also indebted to prof. T. Ito and Assist. Prof. S. Shibasaki of the First Department of Anatomy for their encouragement and advice in electron microscopy as well as to the staffs in both departments for their cooperation.

\section{鼻茸の粘膜結合組織の形質細胞の電子顕微鏡的研究（内容自抄）}

1. ヒトの鼻茸の組織を電子顕微鏡で観察した。鼻茸の上皮下結合組織内には多くの形 質細胞が一般に散在性に，時に小集団をなして見られる。外形は変化にとみ，細胞表面に は粗面小胞体を含む大きい細胞質突起，あるいは微䄉毛状突起が認められることが多い. 時に細胞表面の一部に沿って基底膜が見られるが，pinocytosis を示す像はまれである。

2. 核は偏在し，核膜に沿って数個の電子密度の高い染色質塊が分布し，いわゆる車輻 核の像に相当する所見を示す。まれに一部二重の滑面限界膜で包まれ，電子密度中等度の 


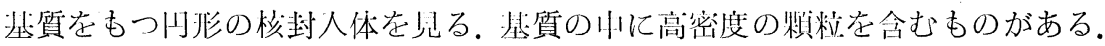

3. 形質細胞の細胞質は，ゴルジ野を除いて，最もよく発達した豊富な粗面小胞体によ って充満する。一般に層板状に密に配列する長い扁平囊から成るが，細胞により形の変化 を示し，また内容の性状にあ多少の変化がある。しかしそれらによって細胞機能を推定す るととはむづかしい，とくにゴルジ野に近接する囊から滑面限界膜をむつ電子密度の高い 小胞が分離形成され，ゴルジ小胞へ加わる。粗面小胞体の限界膜に付着するリボゾームの 配列は不規則で，しばしば環状，時に花環状，ラセン状配列を示す，自由なリボゾームは 少ない。

4. 形質細胞はまたよく発達した大きいゴルジ装置を核に接してもつ. 主としてよく発 達したゴルジ層板と多数のゴルジ小胞から成り, ゴルジ空胞は少ない. 層板と小胞には電 子密度の高い物質を入れるものが多い. 空胞は低密度の内容を入れ, 挖そらく層板の拡大 によって生ずる.

5. 系粒体は主として核周囲部とくにゴルジ野の周囲に, 粗面小胞体囊の間に介在して 分布する.基質内にしばしば高電子密度の直径約 $35-55 \mathrm{~m} \mu$ の系粒体内顆粒が認められる.

6. 形質細胞の双中心子はゴルジ野の内部に存在し, 円筒の細管 (fiber) 配列様式は 9 triplet +0 型である. 対をなす 2 中心子長軸の交叉角は直角ではなく，むしろ鈍角である. 双中心子の一方のみに satellite が認められる。

7. 鼻茸の形質細胞には細胞質内にかなり多くの dense body すなわちリゾゾームが出 現する. 大多数は均質性高密度の基質をもつあので，ゴルジ野の中または近囲に認められ る. その他まれに基質内にさまざまの構造をもつものがある. 前者はゴルジ小胞の融合に よって生じ, 後者はおそらく老化したチトリゾームである.鼻茸の形質細胞の細胞質内に まれに出現するチトリゾームは明瞭な滑面限界膜で包まれ，変性した粗面小胞体，系粒体， multivesicular body などを入れる。

8. Russell 小体をむつ形質細胞は少ない.すべて粗面小胞体膜で包まれ，小胞体の蛋白 に由来すると思われるが，2型に分けられる，1つは拡大した粗面小胞体囊を均質性高密 度の物質が充満した型で，粗面小胞体膜と高密度の物質の間に明間隙を残さない。他は小 数の拡大した粗面小胞体囊の中に高密度の球形顆粒が出現し, 限界膜との間に間隙が認め られるもので，膵外分泌細胞の intracisternal granule に似る.

9. ヒトの鼻茸の形質細胞には, 細胞質内にかなりの頻度に結晶様構造が認められる.そ れらを 1) 粗面小胞体囊内に出現し, 針状あるいは紡鍾形のもの，2）滑面限界膜でつつま れ，多角形で最む多く現われるもの，3) 桿状で限界膜不明のものに分類できる。いづれも 恐らく蛋白質の結晶である.

そのほか形質細胞に拈ける抗体産生機序について論じた。

\section{References}

Amano, S.: Studies on plasma cells-cytogenesis, defensive function and ultracytophysiology. A review of our original studies since 1944. Annu. Report Inst. Virus Res. Kyoto Univ., Ser. 
A, 1:1-47 (1958).

Amano, S., and H. Tanaka : Further observation of the plasma cell generation from the vascular adventitial cells through metamorphosis by ultrathin sections under electron microscope. (Japanese text.) Acta haematol. jap. $19: 738-741$ (1956).

Ashford, T. P., and K. R. Porter: Cytoplasmic components in hepatic cell lysosomes. J. Cell Biol. $12: 198-202(1962)$.

Bernhard, W., and N. Granboulan: Ultrastructure of immunologically competent cells. In: A ciba foundation symposium on cellular aspects of immunity. London, J. \& A. Churchill, 1960. (p. 92-121).

Bessis, M.: Ultratructure of lymphoid and plasma cells in relation to globulin and antibody formation. Lab. Invest. $10: 1040-1067$ (1961).

- : Lymphoid tissue. In: (ed. by) Stanley M. Kurtz: Electron microscopic anatomy. New York-London Academic Press, 1964. (p. 183-198).

Bessis, M., and J. P. Thiéry: Electron microscopy of human white blood cells. In: (ed. by) G.H. Bourne and J. F. Danielli: Int. Rev. Cytol. 12:199-241 (1961).

Braunsteiner, H., K. Fellinger, and F. Pakesch : Demonstration of a cytoplasmic structure in plasma cells. Blood $8: 916-922$ (1958).

Braunsteiner, H., and F. Pakesch : Electron microscopy and the functional significance of a new cellular structure in plasmocytes: A review. Blood $10: 650-654$ (1955).

Brecher, G., Y. Tanaka, R. A. Malmgren, and J. L. Fahey: Morphology and protein synthesis in multiple myeloma and macroglobulinemia. Ann. New York Acad. Sci. 113:642-653 (1964).

Brittin, G. M., Y. Tanaka, and G. Brecher: Intranuclear inclusions in multiple myeloma and macroglobulinemia. Blood $21: 335-351$ (1963).

Clark, S. L.: The synthesis and storage of protein by isolated lymphoid cells. Examined by autoradiography with the electron microscope. Amer. J. Anat. 199:375-404 (1965).

Gonfer, D. S., and R. J. Stenger: The evolution of lysosomes in hypoxic liver parenchyma as seen with the electron microscope. Amer. J. Pathol. 45 : 533-546 (1964).

Goons, A. H., E. H. Leduc, and J. M. Gonnolly: Studies on antibody production. I. A method for the histochemical demonstration of specific antibody and its application to a studies of the hyperimmune rabbit. J. exp. Med. 22 : 49-59 (1955).

Deane, H. W. : Some electron microscopic observations on the lamina propria of the gut, with comments on the close association of macrophages, plasma cells and eosinophils. Anat. Rec. 149: 453-473 (1964).

Dohi, S., M. Hanaoka, and S. Amano: The finer structures of the plasma cell as observed in electron microscope-Endoplasmic reticulum with Russell bodies, Golgi filaments, centrioles and chromonema. (Japanese text.) Acta haematol. jap. 19:3-8 (1956).

Dolowitz, D. A., and T. F. Dougherty: Nasal polyposis. Arch. Otolaryngol. 74: 171-177 (1961).

Fagraeus, A.: The plasma cellular reaction and its relation to the formation of the antibodies in vivo. J. Immunol. $58: 1-18$ (1948).

Fawcett, D. W.: Centrioles. In: The cell. Philadelphia-London, W. B. Saunders 1966 (p. 49-62),

Gedrat, J., J. Monnier, J. Izard, R. Bourse, et J. F. de Boissezon: Étude en microscopie électronique d'inclusions intranucléaires dans une plasmocytose médullaire atypique avec dysglobulinémie. Bull. Cancer 50 : 251-261 (1963).

Guzman, I. G.: Cytogenesis and significance of the plasmocytes. Proc. 8th int. Conger. Hematol. $2: 692-696$ (1962).

Hirsch, G. C. : Die Integration der Geschehnisse in der Zellen des exokrinen Pankreas. Proc. 16th Gen. Assem. Jap. Med. Congr. 1:97-114 (1963).

Ichihara, M.: Histological studies of nasal polyps. (Japanese text.) Otologia (Tokyo) 33 : 701-704 (1961).

Ichikawa, A.: Fine structural changes in response to hormonal stimulation of the perfused canine pancreas. J. Cell Biol. 24 : 369-385 (1965). 
Ito, T., T. Takahashi, und Y. Mizutani : Über den Golgi apparat der :Plàsmazellen, mit besonderer Berücksichtigung auf des Wesen des hellen Hofs derselben. Fol. anat. jap. 16:303-314 (1938).

Kinugawa, Y.: Pathologisch-histologische Untersuchungen der Nasenschleimhaut mit besonderer Berücksichtigung des Vorkommens von Russell'schen Körperchen. (Japanese text.) J. Otorhino-laryngol. Soc. Jap. 34 : 779-798 (1928).

Kurosumi, K.: Fine structure of the cell and material transportation, with special reference to the absorption and excretion. (Japanese text.) J. clin. Science (Tokyo) 1:1-18 (1965).

Luft, J. H.: Improvements in epoxy resin embedding methods. J. biophys. biochem. Cytol. 9 : 409414 (1961).

Mazia, D.: Reproduction of the mitotic centers. In: (ed. by) J. Brachet and A. E. Mirsky: The cell. New York London, Academic Press, 1961 (vol. 3, p. 166-139).

Matsumori, S., O. Inui, and H. Kawaguchi : Five cases of antrochoanal polyps. (Japanese text.) Pract. Otol. (Kyoto) $53: 176-181$ (1960).

Moe, R. E.: Electron microscopic appearance of the parenchyma of lymph nodes. Amer. J. Anat. 114: 341-369 (1964).

Movat, H. Z., and N. V. P. Fernando : The fine structure of connective tissue. II. The plasma cell. Exp. mol. Pathol. 1:535-553 (1962).

Movat, H. Z., and D. R. Wilson: The fine structure of plasma cells in relation to their function. Can. Med. Assoc. J. 81 : 154-159 (1959).

Nossal, G. J. V.: Antibody production by single cells. Nature 181 : 1419-1420 (1958).

Nossal, G. J. V., and O. Mäkelä: Autoradiographic studies on the immuno response. I. The kinetics of plasma cell proliferation. J. exp. Med. 115:209-230 (1962).

Novikoff, A. B.: Lysosomes and related particles. In: (ed. by) J. Brachet and A. E. Mirsky: The cell. New York-London, Academic press, 1961 (vol. 11, p. 423-488).

Novikoff, A. B., and E. Essner: Cytolysomes and mitochondrial degeneration. J. Cell Biol. 15: 140-146 (1962).

Ortega, L., and R. Mellors: Cellular sites of formation of gamma globulin. J. exp. Med. 106:627 (1957).

Paraskevas, F., J. Heremans, and J. Waldenström : Cytology and electrophoretic pattern in gamma 1 A (beta 2A) myeloma. Acta Med. scand. 170:575-589 (1961).

Pearse, A. G. E.: The nature of Russell bodies and Kurloff bodies; observation on the cytochemistry of plasma cells and reticulum cells. J. clin. Pathol. 2:81-90 (1949).

Petris, S., G. Karlsbad : Localization of antibodies by electron microscopy in developing antibodyproducing cells. J. Cell Biol. $26: 759-778$ (1965).

Russell, W.: An address on a characteristic organism of cancer. Brit. med. J. 2 : 1356 (1890).

Sekine, M.: Histologische und cytoloeische Untersuchungen über die apokrinen Schweißdrüsen der Gesichtsdrüse von der Fledermaus, Rhinolopus ferrum-equinum nippon. 2. Elektronenmikroskopische Beobachtung. Arch. histol. jap. 26 : 281-327 (1966).

Stöbbe, H. : About the secretion mechanism of the plasma cell. Proc. 8th int. Congr. Hematol. 2 : 865-869 (1962).

Stockinger, L. : Elektronenoptische Darstellung einer Makroglobulinretention in Plasmazellen des Menschlichen Knochenmarks. J. Cell Biol. 15 : 131-136 (1962).

Stoeckenius, W.: Golgi-Apparat und Centriol menschlicher Plasmazellen. Frankf. Z. Pathol. 68 : 404-409 (1957 a). : Weitere Untersuchungen am lymphatischen Geweben. Verhandl. Deut. Ges. Pathol. 41 : 304-312 (1957 b).

Tanaka, H., M. Hanaoka, and S. Amano: Observationson the centriole of interkinetic blood cells under the electron microscope by ultra-thin sections. Relationship between the centrioles and Golgi canaliculi. (Japanese text.) Acta haematol. jap. 20 : 85-98 (1957).

Thiéry, J. P.: Étude sur le plasmocyteà l'état vivant. II. Excrétion de vacuoles d'origine nucleaire. 
Rev. Hématol. 12:211-221 (1957).

: Étude sur le plasmocyte en contraste de phase et en microscopic éléctronique. Rev. Hématol. $13: 61-78$ (1958).

: Microcinematographic contributions to the study of plasma cells. In: A Ciba Fundation Symposium on Cellular Aspects of Immunity. London, J. \& A. Churchill. 1960 (p. 59-91).

Tokumaru, M.: Nasal polyp tissue studies under electron microscope. (Japanese text.) Otol. Fukuoka 9 : 197-200 (1963).

Watanabe, Y., M. Takamatsu, and R. Osako: Fine structure of plasma cell as revealed by electron microscope. (Japanese text.) J. Electronmicroscopy $3: 146-151$ (1956).

Wellensiek, H. J. : Zur submikroskopischen Morphologie von plasmazellen mit Russelchen Körperchen und Eiweißkristallen. Beitr. Pathol. Anat. 118:173-202 (1957).

Welsh, R. A. : Electron microscopic localization of Russell bodies in the human plasma cell. Blood $16: 1307-1312(1960)$.

: Light and electron microscopic correlation of the periodic acid-Schiff reaction in the human plasma cell. Amer. J. Pathol. 40 : 285-296 (1962).

White, R. G.: Observation on the formation and nature of Russell bodies. Brit. J. exp. Pathol. 35 : 365-376 (1954).

Yago, T.: Clinical and histopathological studies of nasal polyps (Jaranese text.) J. Oto-RhinoLaryngol. Soc. Jap. 63 : 154-173 (1960).

Yamasaki, K. : Histopathological studies of nasal polyp. 1. General histopathological remarks of nasal polyp. (Japanese text.) J. Oto-Rhino-Laryngol. Soc. Jap. $57: 66-71$ (1954). 